\title{
Effects of co-substrates' mixing ratios and loading rate variations on food and agricultural wastes' anaerobic co-digestion performance
}

\author{
Nour El Houda Chaher ${ }^{1,2,3} \cdot$ Nils Engler $^{4} \cdot$ Abdallah Nassour $^{2} \cdot$ Michael Nelles $^{2,4}$
}

Received: 26 March 2021 / Revised: 2 June 2021 / Accepted: 12 June 2021

(c) The Author(s) 2021

\begin{abstract}
Tunisia is one of the developing countries which faces crucial challenges, the most prominent of which are the production of organic waste, the need for an appropriate waste treatment, and the demand for water and energy conservation. To this end, the present research was designed to develop a technical concept on closed cycle "biowaste to bioenergy" treating food waste (FW) through combined biological processes. In this approach, semi-continuous anaerobic co-digestion (ACoD) of $\mathrm{FW}$, wheat straw (WS), and cattle manure (CM) was tested to investigate the relationship between the effect of the feedstock mixtures and $\mathrm{C}: \mathrm{N}$ ratio on biogas and digestate generation at different organic loading rates (OLRs) ranging from 2 to $3.6 \mathrm{~kg}$ $\mathrm{VS} / \mathrm{m}^{3}$.d. Results showed that the mono-digested FW was optimal and reached $565.5 \mathrm{LN} / \mathrm{kg} \mathrm{VS}_{\text {in }}$ at an OLR of $2.4 \mathrm{~kg} \mathrm{VS} /$ $\mathrm{m}^{3} . \mathrm{d}$, and then a drop of biogas production was recorded. However, for co-digested substrates, the optimum mixture ratio was FW:CM 75:25, where $62 \%, 39.89 \%, 91.26 \%, 130.9 \%$, and $119.97 \%$ of the biogas yield improved for OLRs ranging from 2 to $3.6 \mathrm{~kg} \mathrm{VS} / \mathrm{m}^{3}$.d, respectively. Admittedly, the target of this work was to enhance the ACoD process, but it also examined the exploitation of different AD effluents. Therefore, special attention was paid to the generated digestates to decide how it can be efficiently upcycled later. Thus, the closed cycle "biowaste to bioenergy" treatment met two of the major Tunisian concerns: efficient organic waste management and sustainable bioenergy production.
\end{abstract}

Keywords Food waste $\cdot$ Cattle manure $\cdot$ Wheat straw $\cdot$ Anaerobic digestion $\cdot$ Organic loading rate $\cdot$ Process stability $\cdot$ AD effluents

\section{Introduction}

In recent decades, the increased amounts of solid organic wastes have become a worldwide challenge as it creates alarming environmental concerns [1]. Landfills and/or open dumpsites are considered as the common practice for

Nour El Houda Chaher

nour.chaher@uni-rostock.de

1 Department of Chemical and Process Engineering, National Engineering School of Gabes, University of Gabes, 6029 Gabes, Tunisia

2 Department of Waste and Resource Management, Faculty of Agrar and Environmental Sciences, University of Rostock, 18059 Rostock, Allemagne

3 Department of Biological and Chemical Engineering, National Institute of Applied Sciences and Technology, University of Carthage, 1080 Tunis, Tunisia

4 DBFZ German Biomass Research Center GmbH, 04347 Leipzig, Germany municipal solid waste (MSW) disposal all over the world. For instance, in the USA, $52.6 \%$ of MSW was discarded in landfills, in Brazil 59.1\%, in the Kingdom of Saudi Arabia (KSA) 85\%, in Malaysia 94.5\%, and in China 79\% [2]. Moreover, a particular attention should be paid with this regard to Tunisia where up to $95 \%$ of MSW is landfilled without any pretreatments which aggravates the situation in the country in terms of waste management issues, environmental, as well as socio-economic features [3]. Hence, the alarming situation of Tunisia makes the implementation of a sustainable waste management system a priority in order to reduce the caused environmental concern. In the same context, the actions taken by the European community are a model to deal with, as it increasingly moves from landfilling toward recycling and reuse [4]. In fact, since 2016, the directive in force comprises requirements for the reduction of waste amounts disposed in landfills, when member countries are not allowed to landfill more than $35 \%$ of biodegradable MSW to reduce any kinds of pollutant emissions [5]. In fact, the principal sources of emissions from landfill sites are as 
follows: the waste materials as they are brought onto site; emissions from transport; waste blown by the wind; dust generated from the landfill surface; landfill gas generated; and leachate formation [3] [6].

The lack of appropriate organic waste management in Tunisia not only poses problems in the landfill areas, but it also leads to a dead-end track with regard to the loss of the valuable organic residues which constitutes $68 \%$ of the total solid stream [7]. Since organic wastes contain high moisture content (MC), volatile solids (VS), and salinity (EC), any improper disposal practices will result in leachate and greenhouse gas (GHG) emissions and, in turn, to significant environmental concerns in one hand [8]. On the other hand, as the organic residues are considered as a valuable source of macro- and micronutrients including nitrogen $(\mathrm{N})$, carbon $(\mathrm{C})$, potassium $(\mathrm{K})$, and phosphorus $(\mathrm{P})$, inappropriate organic waste management implies not only environmental issues but also significant nutrient losses [9]. Thus, effective biowaste exploitation must receive adequate attention as it is the most appropriate technology to take advantage of the significant volume of biomass produced in the study area as well as to recover beneficial compounds exploited to enhance the natural material cycle [10] [11].

In this regard, anaerobic digestion (AD) is recognized as a well-established engineering concept ensuring the reduction of various streams of organics and reducing the GHG while producing sustainable energy [12]. However, several parameters should be considered as basic criteria to ensure the process progress. In terms of $\mathrm{AD}$ performance, substrate structure, moisture content (MC), carbon to nitrogen (C:N) ratio, soluble/insoluble solids, as well as macro- and micronutrient concentrations, and more particularly $\mathrm{P}$ and $\mathrm{K}$, have to be carried out [13] [14]. While in terms of AD effluent quality, some hygienic precautions have to be taken. In fact, organic residues which embody meat or meat products, or which originate from livestock breeding, can contain pathogenic microorganisms that are of sanitary concern when applying AD digestate to agricultural land [15]. Thus, in the European Union (EU), pasteurization at $70{ }^{\circ} \mathrm{C}$ for $1 \mathrm{~h}$ is the defined standard for meat-containing wastes from food processing, food waste from households and restaurants, and slaughterhouse waste of animals which are then suitable to deliver products for human consumption such as biofertilizers [16] [17]. Moreover, several studies evaluate various approaches intending to examine the removal rate of pathogenic microorganisms achieved through thermal pretreatment [18]; chemical pretreatment such as ozonation; electro-technology such as pulsed electrical field or highvoltage discharge [19]; or physicochemical methods such as ultrasound technology, microwave irradiation, or hydrostatic pressure [20]; however, it should be mentioned that the thermal sanitization is most commonly applied. In this context, Zhang et al. (2020) tested the effect of pasteurization at $70{ }^{\circ} \mathrm{C}$ for $1 \mathrm{~h}$ on anaerobic treatment of various organics and revealed that the disinfection can positively impact the methane yield of some specific substrates, such as potato waste and animal blood, whereas pasteurization of food waste, cattle slurry, and card packaging had no significant impact on methane yield during anaerobic digestion [21]. Hence, to ensure a sustainable biological process as well as a highly qualified end-products, the selection of the appropriate biomass is challenging [22] [23].

When it comes to economic viability, treatment performance, as well as process capacity to manage different kinds of biowaste, anaerobic co-digestion (ACoD) seems to be the most advantageous solution relieving several environmental and energic concerns. As FW mono-digestion is often prone to acidification, ammonia, and long-chain fatty acid inhibition, the selection of suitable co-substrates is considered a key factor enhancing the stability of the process [24] [25]. In general, the choice of co-substrates for $\mathrm{FW}$ anaerobic treatment is done referring to their high buffering capacity, capacity on C:N ratio regulation, and the broad range of nutrients required by the methanogens, etc. [26] [27]. In this light, agricultural residues are considered as attractive co-substrates to be exploited for biological treatments and aerobic and anaerobic processes. Furthermore, based on the availability of agricultural streams in Tunisia as well as the appropriateness of biowastes to enhance FW anaerobic digestion, cattle manure (CM) and wheat straw (WS) are the most pertinent residues to be exploited [28].

On one hand, most of the studies focusing on FW-ACoD have been carried out using CM or WS separately [29] [30]. On the other hand, the co-digestion of manures and straws has been widely studied [26] [31]; however, few studies have considered the mixtures of the three substrates simultaneously by varying the mixture ratios, which is the first target of the current research work. Moreover, most of the previous work has been carried out under batch conditions [27] [32] [33]; while under such conditions, it is hard to determine the reasons causing the inhibition or failure of the process [34]. To this end, continuous mode is widely recommended to be able to evaluate the strength of the AD process by monitoring several parameters including the organic loading rate (OLR) [34]. As the latter is a pre-eminent factor in precisely controlling the efficiency of the process, the evaluation of OLR variation effects on the AD's progress is the second target of the experimental work.

Numerous papers consider the ACoD of different kinds of biomass as a booster of methane yields, while few have focused on its effect on the digestate quality as well as its significant impact on the selection of the suitable post-treatment of the AD residue [26] [27]. So, to unlock the full sustainability potential of anaerobic treatment, both AD effluents and biogas and digestate have to be efficiently exploited [35]. Therefore, at the end of the experimental works, special 
attention is paid to the effects of substrate mixtures on the digestate characteristics collected from each reactor.

To sum up, the present research work aims to bridge the gap in knowledge related to the feasibility of biological treatment of different types of organic residues generated particularly in Tunisia as well as the anaerobic process stability. Thus, it critically evaluates the potential of ACoD of the dominant streams of biowastes generated in the studied area (i.e., FW, WS, and CM) by focusing on the impact of different mixing ratios, $\mathrm{C}: \mathrm{N}$ ratio adjustment, as well as loading rate variations on key downstream $\mathrm{AD}$ effluents: biogas and digestate.

\section{Overall concept}

The research work was launched in the framework of "RenewValue project" aiming to optimize the exploitation of different types of biowastes: FW, WS, and CM. The overall concept followed in the project is illustrated in Fig. 1. To this end, the experimental work was fundamentally divided into two phases. During the first, the input materials (FW, WS, $\mathrm{CM}$ ) were subjected to $\mathrm{AD}$, while the second phase was assigned to the recovery of the by-products.

In this approach, the main target was the selection of the most effective mixing ratios of food and agricultural wastes as feedstocks of semi-continuous anaerobic digesters basing on volatile solid (VS) mass. The selection of the exploited biowaste was based on their availability, their efficiency to adjust the initial $\mathrm{C}: \mathrm{N}$ ratio and improve the process performance, as well as their influence on the by-product's characteristics: biogas and digestate [36]. Over the experimental work, $\mathrm{pH}$ was held without any rectification to evaluate its combined effect with the OLR variations as this might be the best way of roughly estimating real conditions on a large scale.

\section{Materials and Methods}

\subsection{Substrates and inoculum selection}

The main target of the experimental work was to treat biologically different kinds of organic residues which are generated abundantly in the study area. Therefore, the selection of biowastes had to be rigorous, particularly with regard to the quality of $\mathrm{AD}$ effluents such as biogas and digestate. To this end, two criteria were considered:

- Biowastes availability in the selected study area: Tunisia

- "Positive list" illustrating the end-of-waste characteristics for biodegradable waste subjected to biological treatment (compost and digestate) [37]

Accordingly, three kinds of organic residues were chosen as feedstock materials; FW was used as the main substrate, while CM and WS were exploited as potential co-substrates for semi-continuous ACoD.

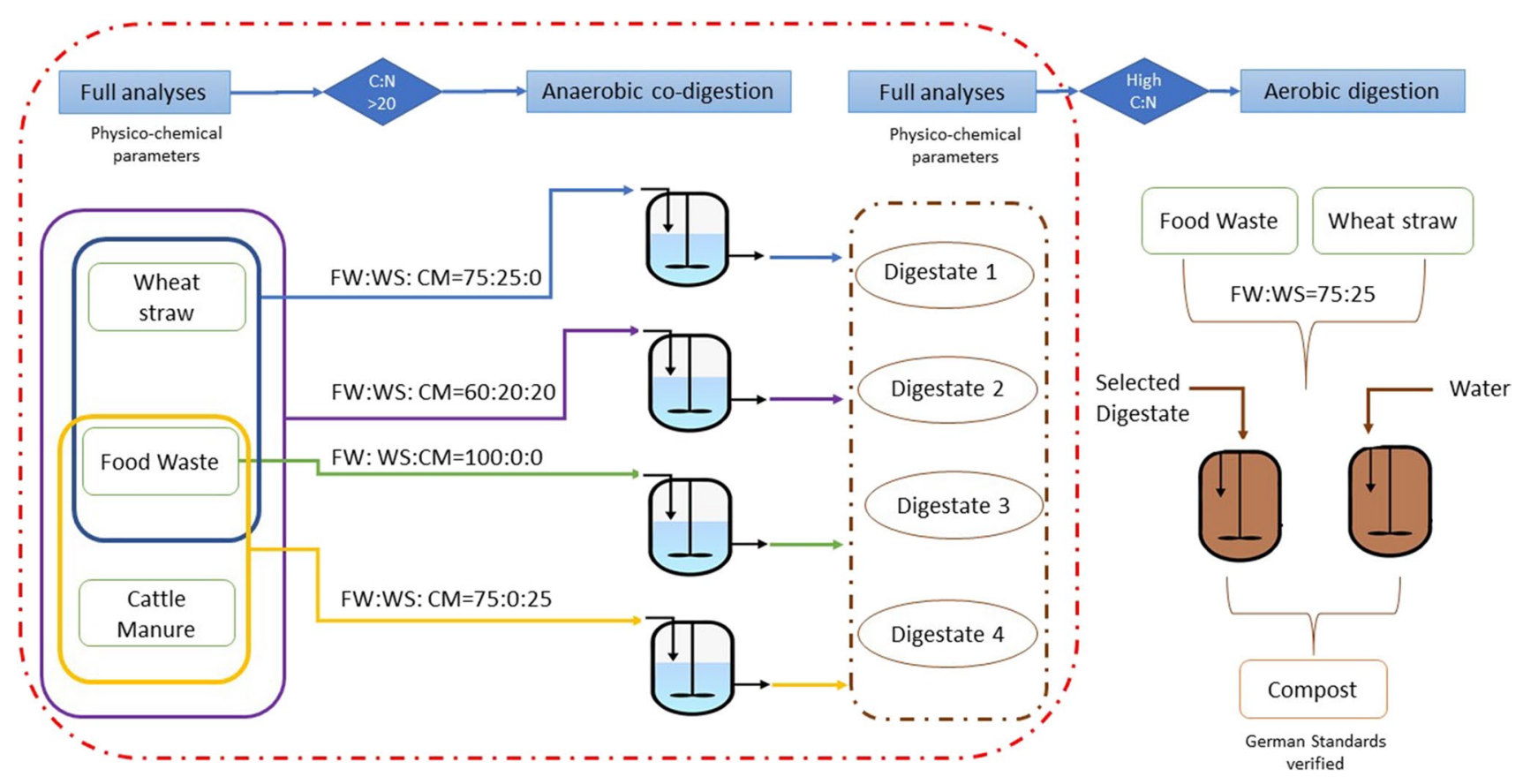

Fig. 1 Conceptualization of the overall "RenewValue" approach 


\subsection{Sample's preparation}

Food waste, which is mainly composed of rice, noodles, salads, and bread, was firstly gathered from the canteen of the University of Rostock, Germany. However, WS and CM were provided by a cattle farm in the vicinity of Rostock. To improve the mixture aspect, with reference to Ngan et al. (2020), physical pretreatments of WS and FW were carried out to reduce the particle size within the range of 15 to $25 \mathrm{~mm}$ using a lab blender type GRINDOMIX (Retsch $\mathrm{GmbH}$, Germany) [38]. In fact, the size reduction of the feedstock, more particularly WS which is known by its high cellulose or lignin content, increased its solubility, enhanced the reduction of volatiles and solid content, and, in turn, boosted biogas production [39]. Once the physical pretreatment was achieved, WS and FW were stored in plastic airtight buckets kept at $-20^{\circ} \mathrm{C}$ to stop any biological reaction.

The start-up of an anaerobic digester is significantly influenced by the quality of the inoculum used as it plays a crucial role in supplying the reactors with acclimatized microorganisms as well as the required trace elements (TEs) [40]. Therefore, to set a desired anaerobic start-up condition, the inoculum was collected from a biogas plant treating FW under mesophilic conditions. At the beginning of the process, the inoculum was held anaerobically at $37{ }^{\circ} \mathrm{C}$ for several days to minimize background biogas production.

\subsection{Experimental setup}

The experiments were carried out in mesophilic lab digesters with a nominal volume of $20 \mathrm{~L}$. The digesters were conserved in climatic chamber with forced air ventilation to keep the reactor temperature under mesophilic conditions, around $38 \pm 1{ }^{\circ} \mathrm{C}$. An internal stirrer (anchor-type) was installed in each digester. Each was stirred for 5 min every $30 \mathrm{~min}$ at an approximate speed of 80 (rounds per minute) $\mathrm{rpm}$. Reactors were equipped with inlet and outlet valves for feeding and digestate withdrawal. Except on weekends, the reactors received different mixtures of organic wastes twice per day. The hydraulic retention time (HRT) was maintained for 30 days [41], and the OLR ranged between 2.0 and $3.6 \mathrm{~kg}$ $\mathrm{VS} / \mathrm{m}^{3} . \mathrm{d}$ with a stepwise of 0.4 . Each tested set of parameters was performed in duplicate (Fig. 2).

To ensure the preciseness of parameter measurement, VDI Guideline 4630 (2016) has been considered as a reference to achieve almost all the experimental analyses [42]. With regard to the gas volume measurement, it was carried out with micro-gas meter (Bergedorf fermentation test), the biogas which forms was routed to a micro-gas meter (type TG05, RITTER Mess Technik GmbH, Germany) whose central component was a rotatable hollow tilting cube of defined and calibrated volume. The electronic pulse created by tilting movement ultimately generated gas formation diagrams by means of a PC and measurement acquisition software. Moreover, the composition of the obtained biogas $\left(\mathrm{CH}_{4}\right.$, $\mathrm{CO}_{2}, \mathrm{H}_{2} \mathrm{~S}$, and $\mathrm{O}_{2}$ ) was analyzed directly at the gas outlet of the devise. To this end, the headspace of each digester was analyzed every other day using a gas analyzer type EHEIM VISIT 30 (Eheim Mess Technik GmbH, Germany). When it comes to liquid sampling, a largely representative sample was obtained weekly ensuring triplicate analysis to validate the results. Therefore, samples from the digester content were taken once per week via the feeding port to examine total solid (TS), volatile solid (VS), volatile fatty acids (VFAs), alkaline buffer capacity (TAC), $\mathrm{pH}$, and VFA:TAC ratio [42]. This latter was assessed as one of the process stability indicators which was weekly controlled to find out whether the OLR can be increased (Sect. 4.4).

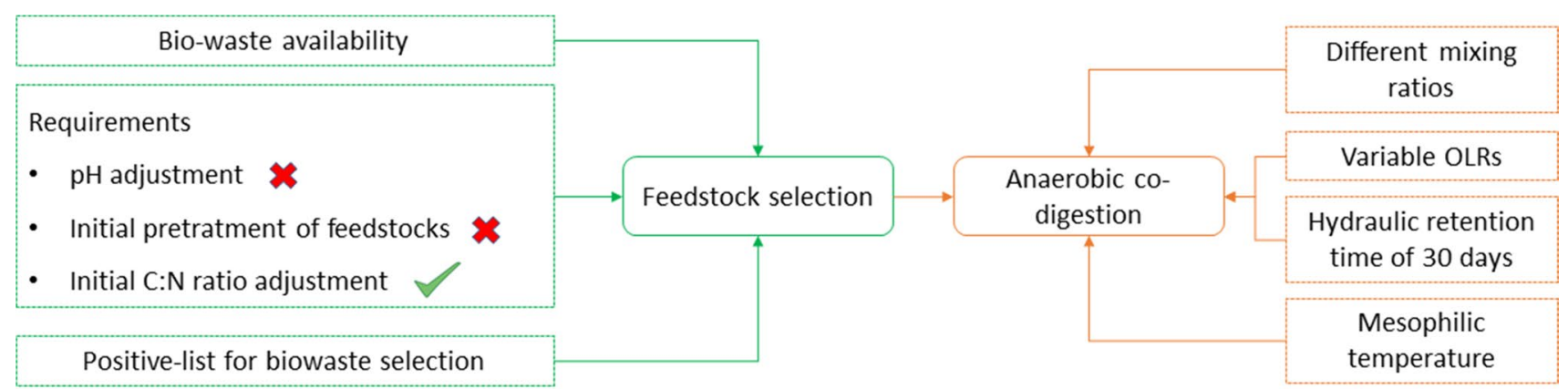

Process requirements: Operational conditions

Project requirements: Selection of raw organic material

Fig. 2 Experimental scheme of 'RenewValue' approach 


\subsection{Analytical methods}

The substrates FW, WS, CM, and D $(\mathrm{i}=1,2,3$, 4) were characterized by measuring different physical and chemical parameters. Therefore, three representative samples were taken to identify different parameters. As such, MC, TS, and VS contents were determined gravimetrically following CENT/TS 14,744-1 (2009). In addition, C:N ratio and major and minor mineral content analysis of the whole substrates were determined in an external laboratory following the methods described in EN ISO 16,967 (2015) and 15,297 (2011), respectively (Table 1).

Regarding the operational parameters assessing the $\mathrm{AD}$ stability, weekly, VFAs, TAC, $\mathrm{pH}$, and VFA:TAC ratio were determined using an automated titration unit type Titra-Lab 1000 (Hach instruments), centrifuging a digestate sample at $4000 \mathrm{rpm}$ for $30 \mathrm{~min}$ to obtain a supernatant. Then, $5 \mathrm{~mL}$ of the latter was used for a titration with $0.1 \mathrm{~mol} / \mathrm{L}$ sulfuric acid until they reached $\mathrm{pH} 5$ and $\mathrm{pH} 4.4$, respectively, in accordance with USEPA (1983). The volume of biogas was normalized to standard conditions comprising dry gas and standard temperature and pressure $\left(0{ }^{\circ} \mathrm{C}\right.$ and 1 bar $)$ according to the method described by Somashekar et al. (2014), the results of which are presented as norm-liters $\left(\mathrm{L}_{\mathrm{N}}\right)$.
Table 2 Physiochemical characteristics of the raw materials

\begin{tabular}{llrrr}
\hline Parameters & Units & \multicolumn{1}{l}{ FW } & \multicolumn{1}{l}{ CM } & \multicolumn{1}{l}{ WS } \\
\hline Total solids & \% of FM & 26.00 & 11.50 & 91.10 \\
Volatile solids & \% of FM & 24.50 & 8.90 & 86.80 \\
Crude ash $\left(550{ }^{\circ} \mathrm{C}\right)$ & \% of FM & 5.80 & 22.60 & 4.70 \\
Moisture content & \% of FM & 74.00 & 88.50 & 8.90 \\
Carbon $(\mathrm{C})$ & \% of FM & 20.52 & 42.61 & 47.63 \\
Nitrogen $(\mathrm{N})$ & \% of FM & 1.20 & 1.70 & 0.61 \\
C:N ratio & & 17.10 & 25.64 & 78.08 \\
Sulfur $(\mathrm{S})$ & \% of TS & 0.33 & 0.50 & 0.16 \\
Phosphors $(\mathrm{P})$ & \% of TS & 0.48 & 0.60 & 0.06 \\
Potassium $(\mathrm{K})$ & \% of TS & 0.91 & 2.95 & 1.74 \\
Magnesium $(\mathrm{Mg})$ & \% of TS & 0.09 & 2.82 & 0.25 \\
Calcium $(\mathrm{Ca})$ & \% of TS & 0.06 & 0.61 & 0.07 \\
Lead $(\mathrm{Pb})$ & $\mathrm{mg} / \mathrm{kg} \mathrm{TS}$ & 0.91 & 0.85 & 0.21 \\
Copper $(\mathrm{Cu})$ & $\mathrm{mg} / \mathrm{kg} \mathrm{TS}$ & 6.82 & 18.20 & 1.78 \\
Zinc $(\mathrm{Zn})$ & $\mathrm{mg} / \mathrm{kg} \mathrm{TS}$ & 16.33 & 131.00 & 16.6 \\
Nickel $(\mathrm{Ni})$ & $\mathrm{mg} / \mathrm{kg} \mathrm{TS}$ & 0.95 & 6.91 & 5.78 \\
Cadmium $(\mathrm{Cd})$ & $\mathrm{mg} / \mathrm{kg} \mathrm{TS}$ & 0.07 & 0.19 & 0.08 \\
Chrome $(\mathrm{Cr})$ & $\mathrm{mg} / \mathrm{kg} \mathrm{TS}$ & 2.31 & - & 10.50 \\
Arsenic $(\mathrm{As})$ & $\mathrm{mg} / \mathrm{kg}$ TS & 0.57 & 0.28 & 0.07 \\
Mercury $(\mathrm{Hg})$ & $\mathrm{mg} / \mathrm{kg}$ TS & $<0.01$ & $<0.01$ & $<0.01$ \\
\hline
\end{tabular}

${ }^{1} F M$, fresh matter; ${ }^{2} T S$, total solids.

Table 1 Physical and chemical parameter measurements of biowastes opted for biological treatments

\begin{tabular}{|c|c|c|c|}
\hline Parameters & Units & Method of analysis & Reference \\
\hline $\mathrm{pH}$ & - & (1:10 w/v sample:water extract) & ISO 10,390 (1994) \\
\hline Moisture content (MC) & $\%$ of $\mathrm{FM}^{1}$ & Using electronic oven by drying at $105^{\circ} \mathrm{C}$ for $24 \mathrm{~h}$ & NF ISO 11,465 (1994) \\
\hline Total solids (TS) & $\%$ of $\mathrm{FM}^{1}$ & & \\
\hline Total carbon (TC) & $\%$ of $\mathrm{FM}^{1}$ & $\operatorname{TOC}(\%)=((100-\operatorname{Ash} \%) \div 1 / 8)$ & [45] \\
\hline Total nitrogen $(\mathrm{TN})$ & $\%$ of $\mathrm{FM}^{1}$ & Titrimetric methods & NF ISO 11,265 (1995) \\
\hline Phosphorus (P) & $\%$ of $\mathrm{TS}^{2}$ & Atomic absorption spectrometric methods & ISO $11,885(2007)$ \\
\hline Potassium $(\mathrm{K})$ & $\%$ of $\mathrm{TS}^{2}$ & & \\
\hline Volatile fatty acids (VFAs) & $\mathrm{mg} / \mathrm{L}$ & Automated titration unit type Titra-Lab 1000 & [43] \\
\hline Alkalinity (TAC) & $\mathrm{mgCaCO}_{3} / \mathrm{L}$ & & \\
\hline VFA:TAC & - & & \\
\hline Magnesium (Mg) & $\%$ of $\mathrm{TS}^{2}$ & Spectrometer, Thermo-Elemental ICP MS-X Series & ISO 11,885 (2007) \\
\hline Lead $(\mathrm{Pb})$ & $\mathrm{mg} / \mathrm{kg} \mathrm{TS}$ & & \\
\hline Copper $(\mathrm{Cu})$ & $\mathrm{mg} / \mathrm{kg} \mathrm{TS}$ & & \\
\hline Zinc (Zn) & $\mathrm{mg} / \mathrm{kg} \mathrm{TS}$ & & \\
\hline Nickel (Ni) & $\mathrm{mg} / \mathrm{kg} \mathrm{TS}$ & & \\
\hline Cadmium (Cd) & $\mathrm{mg} / \mathrm{kg} \mathrm{TS}$ & & \\
\hline Arsenic (As) & $\mathrm{mg} / \mathrm{kg} \mathrm{TS}$ & & \\
\hline
\end{tabular}

${ }^{1} F M$, fresh matter; ${ }^{2} T S$, total solids. 


\section{Results and discussion}

\subsection{Physical and chemical characteristics of the feedstock material}

The physical and chemical characteristics of the residues are summarized in Table 2. The moisture content was found to be approximately $74.0 \%, 88.5 \%$, and $8.9 \%$ of the fresh matter, leaving behind dry matter contents of $26.0 \%, 11.5 \%$, and $91.1 \%$, with volatile solid contents of $94.2 \%, 77.4 \%$, and $95.3 \%$ for $\mathrm{FW}, \mathrm{CM}$, and $\mathrm{WS}$, respectively. Because microorganisms as well as $\mathrm{AD}$ systems have a certain demand for carbon and nitrogen in any growth environment, $\mathrm{C}: \mathrm{N}$ ratios were evaluated for each substrate. In this context, several research works recommended an adjustment of the initial C:N ratio within the range of 20-40 [31] [29]. To this end, initially the $\mathrm{C}: \mathrm{N}$ ratio of each substrate was determined to be 17.10 for FW, 25.64 for CM, and 78.08 for WS; this latter was marginally higher than the acceptable upper limit for AD [44]. Furthermore, minor minerals as micronutrients are considered as essential supplements for the methanogenic bacteria growth; therefore, mineral concentrations were also examined [45]. In this context, several researchers examined the effect of high or low trace elements' (TEs) concentrations on AD performance and recommended a concentration range of $1 \times 10^{-6}$ and $1 \times 10^{-15} \mathrm{M}$ is considered as an optimal one [46] [47]. Accordingly, certain minor elements such as copper $(\mathrm{Cu})$, cadmium $(\mathrm{Ca})$, lead $(\mathrm{Pb})$, and zinc $(\mathrm{Zn})$ [48], as well as some major constituents such as phosphorus $(\mathrm{P})$, potassium $(\mathrm{K})$, and magnesium $(\mathrm{Mg})$ [47], were monitored. In this light, Vintiloiu et al. (2012) evaluated the limit concentration of various trace elements and revealed that several trace elements and macronutrients have a strong statistically significant effect on the stability of the biogas process, particularly iron and cobalt, as it is considered as microorganism growth boosters [49].

\subsection{Effect of co-substrate addition on start-up conditions of FW-AD under a stable OLR}

In the current research work, FW, WS, and CM were initially analyzed to examine carbon and nitrogen concentrations of each substrate (Table 2). In fact, the identified $\mathrm{C}: \mathrm{N}$ ratio of different organic materials depicts that the abundance of nitrogen contents, particularly for FW and CM or the carbonaceous aspect of WS, makes those residues unsuitable for anaerobic mono-digestion [50]. Therefore, different substrates were combined at different ratios to balance the $\mathrm{C}: \mathrm{N}$ ratio greater than or equal to 20 in compliance with the results of Zahan et al. (2017). Subsequently, for a rigorous evaluation of the regulated $\mathrm{C}: \mathrm{N}$ ratio effects, a constant OLR of $2 \mathrm{~kg} \mathrm{VS} / \mathrm{m}^{3}$.d was kept during the acclimatization phase to assess the potential of ACoD process. Starting with digesters fed with $\mathrm{FW}$ as a mono-substrate (i.e., $\mathrm{FW}_{100}$ ), it was characterized by a $\mathrm{C}: \mathrm{N}$ ratio of 17.10 , while higher $\mathrm{C}: \mathrm{N}$ ratios marked the reactors including co-substrates, to rise from 17.10 to 20.03 for $\mathrm{FW}_{75} \mathrm{CM}_{25}, 33.28$ for $\mathrm{FW}_{75} \mathrm{WS}_{25}$, and 31.64 for $\mathrm{FW}_{60} \mathrm{CM}_{20} \mathrm{WS}_{20}$. However, it is worthy to mention that despite the diversity of the raw materials used in terms of carbon and nitrogen content, balanced C:N ratios for all the trials within the requested range of $20-40$ were noted [51]. Thus, from a physicochemical valuation, the mixture of food and agricultural wastes seems to be a good option to overcome one of the most challenging $\mathrm{AD}$ inhibition factors: feedstock C:N ratio [44][44], expecting more performant process. Thereafter, when it comes to the technical side, the volume of biogas and methane yields produced from each feedstock were monitored under a stable OLR of $2 \mathrm{~kg} \mathrm{VS} / \mathrm{m}^{3} . \mathrm{d}$, including the mono-digested $\mathrm{FW}$ which was considered as a blank test or a reference to determine the impact of additional co-substrates. Table 3 summarized the effect of feedstock mixtures on the start-up conditions as well as the entire process stability evolution and illustrated that $62.07 \%, 27.16 \%$, and $25.45 \%$ of improvement in terms of specific biogas yield (SBY) marked $\mathrm{FW}_{75} \mathrm{CM}_{25}$, $\mathrm{FW}_{75} \mathrm{WS}_{25}$, and $\mathrm{FW}_{60} \mathrm{CM}_{20} \mathrm{WS}_{20}$, respectively. This progress

Table 3 Effect of mixing substrates and C:N ratio regulation on start-up conditions

\begin{tabular}{|c|c|c|c|c|c|c|c|c|c|}
\hline \multirow[t]{2}{*}{ Feedstocks } & \multicolumn{3}{|c|}{ Operational conditions } & \multicolumn{4}{|c|}{ Stability indicators } & \multicolumn{2}{|c|}{$\begin{array}{l}\text { ACoD-effluent } \\
\text { improvement vs } \mathrm{FW}_{100} \\
(\%)\end{array}$} \\
\hline & $\begin{array}{l}\text { OLR (kg } \\
\left.\text { VS } / \mathrm{m}^{3} . \mathrm{d}\right)\end{array}$ & $\mathrm{C}: \mathrm{N}$ ratio & $\begin{array}{l}\text { Duration } \\
\text { (days) }\end{array}$ & $\mathrm{pH}$ & VFAs (mg/L) & $\mathrm{TAC}\left(\mathrm{mg} \mathrm{CaCO} \mathrm{Cl}_{3} / \mathrm{L}\right)$ & VFA:TAC & SBY $(\%)$ & $\operatorname{SMY}(\%)$ \\
\hline $\mathrm{FW}_{100}$ & 2 & 17.10 & 58 & 7.20 & 6010.00 & $21,815.00$ & 0.28 & - & - \\
\hline $\mathrm{FW}_{75} \mathrm{CM}_{25}$ & 2 & 20.03 & 58 & 8.12 & 4913.00 & $21,470.00$ & 0.23 & 62.07 & 51.66 \\
\hline $\mathrm{FW}_{75} \mathrm{WS}_{25}$ & 2 & 33.28 & 58 & 8.20 & 4382.00 & $23,419.00$ & 0.19 & 27.16 & 22.09 \\
\hline $\mathrm{FW}_{60} \mathrm{CM}_{20} \mathrm{WS}_{20}$ & 2 & 31.64 & 58 & 8.16 & 4564.00 & $22,615.00$ & 0.20 & 25.47 & 30.29 \\
\hline
\end{tabular}


ascertained the positive effect of the adjusted $\mathrm{C}: \mathrm{N}$ ratio for all the mixtures on the biogas productivity and outlined more particularly the significant enhancement owing to $\mathrm{CM}$ addition [53]. However, even though all the co-digested mixtures were characterized by an initial C:N ratio within the optimal range for a performant $\mathrm{AD}$ progress, the nature of the introduced co-substrates played a critical role in terms of process efficiency [26]. In fact, the poorest improvement of biogas production marked the reactors characterized by a C:N ratio higher than 30 and more particularly contained WS [31] [54]. It might be due to the complicated lignocellulosic structure of WS making it hardly degradable by the anaerobes, and, in turn, lower SBY improvement characterized both $\mathrm{FW}_{75} \mathrm{WS}_{25}$ and $\mathrm{FW}_{60} \mathrm{CM}_{20} \mathrm{WS}_{20}$. The current results were in accordance with the findings of Hassan et al. (2017) revealing that the optimal range of C:N ratio for ACoD of WS should not exceed 30 to ensure a good progress of the biodegradation [31]. Additionally, Zahan et al. (2018a) identified the effect of both nitrogenous and lignocellulosic residues on anaerobic reactor productivity including also FW as a main substrate and pointed out the significant influence of the initial $\mathrm{C}: \mathrm{N}$ ratio balancing in terms of microorganisms progress and $\mathrm{AD}$ effluent quality [29]. Furthermore, as previously mentioned, under the same experimental conditions, $\mathrm{FW}_{75} \mathrm{CM}_{25}$, which was characterized by a C:N ratio of 20.03, generated the highest SBY compared to the other feedstocks. Although the identified C:N ratio of $\mathrm{FW}_{75} \mathrm{CM}_{25}$ was slightly high compared to $\mathrm{FW}$ $\mathrm{C}: \mathrm{N}$ ratio (17.10), an enhancement of the process performance in terms of both biogas and methane productions was significant reaching around $62 \%$ and $52 \%$ of SBY and SMY improvements, respectively. Therefore, certainly, a balanced utilization of nitrogenous and carbonaceous components is required to improve the $\mathrm{AD}$ performance, but further elements are also needed to boost the microbial community development and functioning [55]. In this light, Fermoso et al. (2019) stated that acetogens and methanogens are more significantly influenced by the availability of some required trace elements (TEs) to ensure an efficient functioning which might explain the tendencies of SBY generated by digesters including $\mathrm{CM}$ as an effective provider of essential microand micronutrients [48] [56]. In the same context, Vintiloiu et al. (2012) analyzed the effects of various micro- and macronutrients on the $\mathrm{AD}$ process stability and reported that $\mathrm{Ni}$, Mo, and $\mathrm{S}$ had a consistent statistically significant effect, while no statistically significant effect could be shown for $\mathrm{Fe}, \mathrm{Co}$, and $\mathrm{Na}$. Accordingly, the relative high contribution of CM in terms of $\mathrm{S}$ and Ni contents reaching $6.91 \mathrm{mg} / \mathrm{kg}$ TS and $0.5 \%$ of TS, both higher than FW and WS' contents, validated the significant potential of $\mathrm{CM}$ to boost the anaerobic treatment efficacity [49]. The same findings were reported by Nordell et al. (2016) confirming that manure is one of the most eminent substrates for biogas production as it stabilizes FW anaerobic processes by contributing the nutrients and TEs needed by the microbial community, particularly methanogens [56]. Hence, under a constant OLR, even if a relatively acceptable range of $\mathrm{C}: \mathrm{N}$ ratio was applicable, which is the case of $\mathrm{FW}_{100}$, a performant process is ensured by mixing different types of biowastes, ensuring the supply of the deficit of further components needed by the coexistent microbial community [45].

\subsection{Effect of co-substrate addition on FW-AD performance under variable OLRs}

\subsubsection{Specific biogas yield}

To evaluate the effects of co-substrate addition on FW-AD under variable OLRs, this latter was increased, every 2 weeks, with a rate of 0.4 to range from 2.0 to $3.6 \mathrm{~kg} \mathrm{VS} /$ $\mathrm{m}^{3}$.d. Starting with mono-digested $\mathrm{FW}\left(\mathrm{FW}_{100}\right)$, digesters generated around $414.2 \mathrm{~L}_{\mathrm{N}} / \mathrm{kg} \mathrm{VS}_{\text {in }}$ at an OLR of $2 \mathrm{~kg} \mathrm{VS} /$ $\mathrm{m}^{3}$.d, while at $2.4 \mathrm{~kg} \mathrm{VS} / \mathrm{m}^{3} . \mathrm{d}$, SBY attained $561.05 \mathrm{~L}_{\mathrm{N}} / \mathrm{kg}$ $\mathrm{VS}_{\text {in }}$, and $35.45 \%$ of biogas improvement was noted. However, with a continuous rise of OLRs, a decline of SBY was logged to fall to 384.9 and then to $310.6 \mathrm{~L}_{\mathrm{N}} / \mathrm{kg} \mathrm{VS}_{\text {in }}$ for 2.8 and $3.2 \mathrm{~kg} \mathrm{VS} / \mathrm{m}^{3}$.d, respectively. Those results were in conformity with several findings examining mono-digested FW and pointed out that an OLR range of 2 to $2.5 \mathrm{~kg} \mathrm{VS} / \mathrm{m}^{3}$.d was deemed as optimal to improve the overall system performance in terms of stability, productivity, and efficiency [45] [57]. Nevertheless, with the continuous feeding of the digesters, $\mathrm{FW}_{100}$ was marked by a failure causing a decline in terms of biogas production at an OLR of $3.6 \mathrm{~kg} \mathrm{VS} / \mathrm{m}^{3} . \mathrm{d}$ (Fig. 3). This was explained by the inappropriate atmosphere caused by FW properties and particularly to the relatively low $\mathrm{C}: \mathrm{N}$ ratio which hindered the anaerobes growth [55] [55]. Hence, mono-digestion of FW is more resistant with moderately low and constant OLRs [58], and basing on the current findings, $2.4 \mathrm{~kg} \mathrm{VS} / \mathrm{m}^{3}$.d was the optimal OLR ensuring a performant development of the process for $\mathrm{FW}_{100}$. When it comes to the potential of co-substrates to improve FW-AD progress, Fig. 3 illustrated that CM and WS influenced positively the biogas productivity; however, the noted improvement depended significantly on the mixing ratios of the feedstock. For instance, at an OLR of $2.4 \mathrm{~kg} \mathrm{VS} / \mathrm{m}^{3} . \mathrm{d}$, the increase of SBY was slightly considerable for the reactor comprising WS, as the improvement ranged between 13.88 and $39.89 \%$ compared to $\mathrm{FW}_{100}$, in the order of $\mathrm{FW}_{75} \mathrm{WS}_{25}$ $(13.88 \%)<\mathrm{FW}_{60} \mathrm{CM}_{20} \mathrm{WS}_{20}(23.20 \%)<\mathrm{FW}_{75} \mathrm{CM}_{25}$ (39.89\%). Therefore, it is worthy to mention that the addition of $\mathrm{CM}$ to $\mathrm{FW}_{60} \mathrm{CM}_{20} \mathrm{WS}_{20}$ and $\mathrm{FW}_{75} \mathrm{CM}_{25}$ created a more suitable environment for the microorganisms functioning in order to consume efficiently the available organic materials [59]. By increasing the OLR to $2.8 \mathrm{~kg} \mathrm{VS} / \mathrm{m}^{3} . \mathrm{d}$, a significant improvement in terms of biogas yield marked 


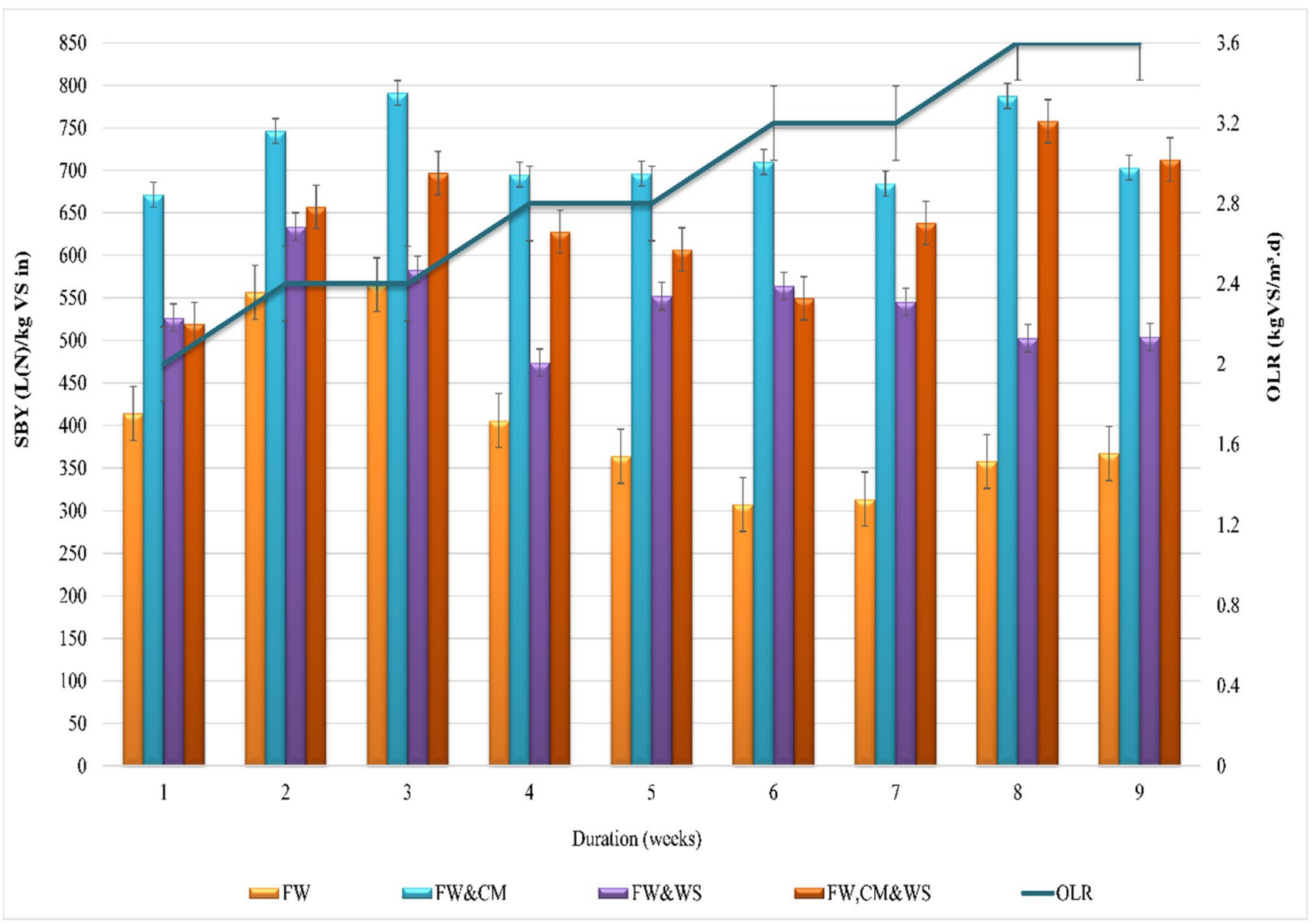

Fig. 3 Specific biogas yields of different mixtures at different organic loading rates

almost all the digesters to be around $51.67 \%, 66.75 \%$, and $91.26 \%$ for $\mathrm{FW}_{75} \mathrm{WS}_{25}, \mathrm{FW}_{60} \mathrm{CM}_{20} \mathrm{WS}_{20}$, and $\mathrm{FW}_{75} \mathrm{CM}_{25}$, respectively, compared to $\mathrm{FW}_{100}$. Hence, the results ascertained the potent of $\mathrm{CM}$ to boost the AD performance with an increased OLR. Moreover, compared to the previous OLRs, $3.2 \mathrm{~kg} \mathrm{VS} / \mathrm{m}^{3}$.d was considered as optimal for almost all the co-digested materials, as peaks in terms of SBY characterizing almost all the digesters were notable (Fig. 3). $\mathrm{FW}_{75} \mathrm{WS}_{25}, \mathrm{FW}_{60} \mathrm{CM}_{20} \mathrm{WS}_{20}$, and $\mathrm{FW}_{75} \mathrm{CM}_{25}$ produced 564.1, 638.0, and $709.8 \mathrm{~L}_{\mathrm{N}} / \mathrm{kg} \mathrm{VS}_{\text {in }}$, respectively, corresponding to $83.5 \%, 103.4 \%$, and $130.9 \%$ of improvement. However, even with an increased OLR higher or equal to $3 \mathrm{~kg} \mathrm{VS} / \mathrm{m}^{3} . \mathrm{d}, \mathrm{FW}_{60} \mathrm{CM}_{20} \mathrm{WS}_{20}$ and $\mathrm{FW}_{75} \mathrm{CM}_{25}$ generated relatively comparable biogas volumes, whereas FW and WS mixture did not. In fact, this latter could not be only due to the hardly degradable cellulosic material, because although $\mathrm{FW}_{60} \mathrm{CM}_{20} \mathrm{WS}_{20}$ included relatively the same fraction of WS comparing to $\mathrm{FW}_{75} \mathrm{WS}_{25}$ and more significant process progress marked the digesters with three substrates: FW, WS, and CM. Accordingly, the effectiveness of CM in terms of digester productivity, under fluctuated loading rates, was one more time highlighted. Similar results were identified by
Zahan et al. (2018) who demonstrated that the combination of FW with chicken litter guaranteed higher process stability and biogas production than FW mixed with lignocellulosic residue mixtures [60]. Reaching higher OLRs, some indicators of reactor inhibition appeared, and almost all the reactors witnessed a drop of biogas production at $3.6 \mathrm{~kg} \mathrm{VS} /$ $\mathrm{m}^{3}$.d. In fact, the decline of biogas production was expected as it was a direct effect of the overloaded digesters followed by an accumulation of volatile acids and then a subsequent process failure (Sect. 4.5).

\subsubsection{Specific methane yield}

The above results depicted that under variable OLRs, anaerobic co-digestion of FW showed an enhanced biogas production, while Fig. 4 illustrated that different specific methane yield (SMY) tendencies were recorded for some feedstock mixtures. At the beginning of the process, SMY improvements were $22.09 \%, 30.29 \%$, and $51.65 \%$ for $\mathrm{FW}_{75} \mathrm{WS}_{25}$, $\mathrm{FW}_{60} \mathrm{CM}_{20} \mathrm{WS}_{20}$, and $\mathrm{FW}_{75} \mathrm{CM}_{25}$, respectively. However, by increasing the OLR to $2.4 \mathrm{~kg} \mathrm{VS} / \mathrm{m}^{3}$.d, a slight decline was noted for $\mathrm{FW}_{60} \mathrm{CM}_{20} \mathrm{WS}_{20}$ and $\mathrm{FW}_{75} \mathrm{WS}_{25}$, which generated 


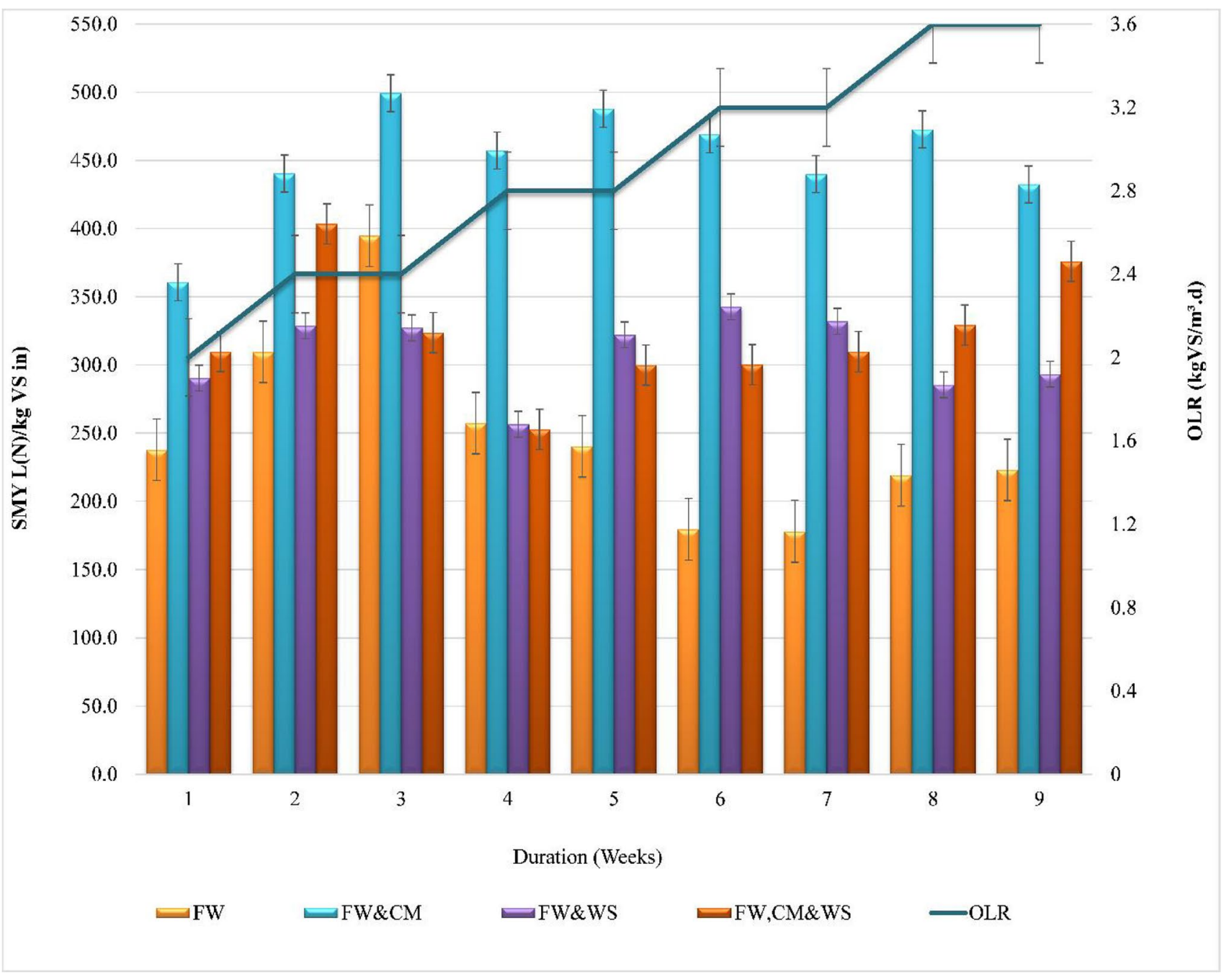

Fig. 4 Specific methane yields of different mixtures at different organic loading rates

$17.13 \%$ and $18.01 \%$ lower methane volumes comparing to $\mathrm{FW}_{100}$. In fact, this drop in terms of methane was explained by the abundance of ready degradable FW components to be rapidly consumed by anaerobes and converted into methane compared to lignocellulosic materials which necessitate more time. Otherwise, a significant enhancement in terms of SMY marked subsequently $\mathrm{FW}_{75} \mathrm{CM}_{25}$, outlining the positive impact of the adjusted $\mathrm{C}: \mathrm{N}$ ratio, and more particularly, it ascertained the relevance of nitrogen-rich residues to boost the methanogens' growth and productivity [61]. However, at an OLR of $2.8 \mathrm{~kg} \mathrm{VS} / \mathrm{m}^{3}$.d, SMYs attained were $103.03 \%$, $33.96 \%$, and $24.83 \%$ for $\mathrm{FW}_{75} \mathrm{CM}_{25}, \mathrm{FW}_{60} \mathrm{CM}_{20} \mathrm{WS}_{20}$, and $\mathrm{FW}_{75} \mathrm{WS}_{25}$, respectively, reaching $161.34 \%, 90.83 \%$, and $73.92 \%$ at an OLR of $3.2 \mathrm{~kg} \mathrm{VS} / \mathrm{m}^{3}$.d. This latter was considered as the optimal OLR ensuring higher methane yielded from all the co-digested materials. The rise of the OLR to $3.6 \mathrm{~kg} \mathrm{VS} / \mathrm{m}^{3}$.d was followed by a drop of SMYs to $93.83 \%$, $30.23 \%$, and $50.20 \%$ for $\mathrm{FW}_{75} \mathrm{CM}_{25}, \mathrm{FW}_{60} \mathrm{CM}_{20} \mathrm{WS}_{20}$, and
$\mathrm{FW}_{75} \mathrm{WS}_{25}$, respectively. Accordingly, $\mathrm{FW}_{60} \mathrm{CM}_{20} \mathrm{WS}_{20}$ and $\mathrm{FW}_{75} \mathrm{WS}_{25}$ showed lower SMY improvement compared to $\mathrm{FW}_{75} \mathrm{CM}_{25}$, which was explained by the rise of TS contents linked to the decline of VS contents, implying in turn limited methane yields [62]. Whereas for risen OLRs, $\mathrm{FW}_{75} \mathrm{CM}_{25}$ showed optimal rendering, which was a result of the buffering capacity of manure as well as the presence of some TEs required to stimulate the activity of enzyme and co-enzymes for better biogas production [45] [63] (Sect. 4.4).

\subsection{Effect of co-substrate addition and variable OLRs on FW-AD process stability}

During the current research work, several parameters were selected to be considered as inhibition indicators for monitoring the process failure of FW-AD including VFAs, TAC, $\mathrm{pH}$, and methane content [64]. In addition, some coupled parameters, such as the ratio between VFA and alkalinity 
was examined by several researchers as reliable early warning and regulation systems, and then it was determined to opt for OLRs increasement effects [65] [66]. However, when comparing the tendencies of the controlled parameters, it must be pointed out that the proposed factors were only valid under certain conditions, operating under a stable and relatively low OLR; some parameters might have different sensitivities to environmental fluctuations in different $\mathrm{AD}$ systems [67]. In fact, at an OLR of $2 \mathrm{~kg} \mathrm{VS} / \mathrm{m}^{3}$.d, the identified alkalinity concentrations from different reactors were almost stable, even for mono-digested FW which depicted a slightly higher TAC concentration of around $21,815.00 \mathrm{mg}$ $\mathrm{CaCO}_{3} / \mathrm{L}$ comparing to $\mathrm{FW}_{75} \mathrm{CM}_{25}(21,470.00 \mathrm{mg} \mathrm{CaCO} / \mathrm{L})$ and moderately lower TAC values measured for digesters including WS, 22,615.00 and 23,419.00 $\mathrm{mg} \mathrm{CaCO}_{3} / \mathrm{L}$ for $\mathrm{FW}_{75} \mathrm{WS}_{25}$ and $\mathrm{FW}_{60} \mathrm{CM}_{20} \mathrm{WS}_{20}$, respectively (Table 4). The obtained values of TAC might be explained by the positive effects of physically pretreated FW and WS on the digestion of biomass, particularly during the acclimatization stage. When it comes to VFA tendencies, different values ranged between 4382.00 and $6010.00 \mathrm{mg} / \mathrm{L}$, where the highest volume of acids marked $\mathrm{FW}_{100}$. It was explained that, during the start-up phase, VFA formation was directly affected by the variable chemical composition of the feeding mixtures [60]. Unexpectedly, $\mathrm{FW}_{100}$ was characterized, initially, by a significant VFA concentration as well as a relatively high alkalinity, which might be linked to the nature and the primary characteristics of the organic residue [63].
Additionally, with regard to $\mathrm{FW}_{100}$, the balance between the significant concentrations of VFAs and TAC served to regulate the initial value of $\mathrm{pH}$ around neutral range which was habitually beneficial for methanogens growth [68]. However, focusing on SMY profile, mono-digested FW produced the lowest volume of methane compared to co-digested feedstocks which ascertained the important role played by the co-substrates in terms of biogas composition enhancement. Table 3 illustrated that approximately $52 \%, 22 \%$, and $30 \%$ of methane yield improvement marked $\mathrm{FW}_{75} \mathrm{CM}_{25}, \mathrm{FW}_{75} \mathrm{WS}_{25}$, and $\mathrm{FW}_{60} \mathrm{CM}_{20} \mathrm{WS}_{20}$, respectively, and confirmed the positive impact of agricultural residues on FW anaerobic cotreatment. Thus, $\mathrm{C}: \mathrm{N}$ ratio and macro- and micronutrients balancing ensured by co-substrate addition boosted the development of methanogenesis phase and, in turn, affected the methane production efficiency [55]. The same findings were figured out by Zahan et al. (2018) revealing that the combination of $\mathrm{FW}$, manure, and straw strengthened the process development and intensified the functioning of methanogens, once the initial C:N ratio was lower than 30 [29]. Certainly, the control of VFAs, TAC, and $\mathrm{pH}$ values was to some extent useful to evaluate the process performance, but the interlink between those different early warning indicators was effective to comprehend the effect of FW-ACoD under a stable OLR.

When it comes to OLR variation, VFA:TAC ratios were identified to evaluate the effects of the risen loading rates in order to optimize this latter for different feedstocks'
Table 4 Anaerobic process performance during OLR variation

\begin{tabular}{llllll}
\hline Feedstock & $\begin{array}{l}\text { OLR }(\mathrm{kg} \mathrm{VS} / \\
\left.\mathrm{m}^{3} . \mathrm{d}\right)\end{array}$ & $\mathrm{pH}$ & $\mathrm{VFA}(\mathrm{mg} / \mathrm{L})$ & $\mathrm{TAC}(\mathrm{mg} \mathrm{CaCO} / \mathrm{L})$ & VFA:TAC \\
\hline $\mathrm{FW}_{100}$ & 2.0 & 7.20 & 6010.00 & $21,815.00$ & 0.28 \\
& 2.4 & 7.03 & 4133.00 & $16,566.00$ & 0.25 \\
& 2.8 & 6.83 & 3732.00 & $12,051.00$ & 0.31 \\
& 3.2 & 6.13 & 3502.00 & 9273.00 & 0.38 \\
& 3.6 & 5.67 & 3797.00 & 7959.00 & 0.48 \\
$\mathrm{FW}_{75} \mathrm{CM}_{25}$ & 2.0 & 8.12 & 4913.00 & $21,470.00$ & 0.23 \\
& 2.4 & 7.60 & 3533.00 & $18,802.00$ & 0.19 \\
& 2.8 & 8.10 & 3671.00 & $19,721.00$ & 0.19 \\
& 3.2 & 7.81 & 4845.00 & $17,974.00$ & 0.27 \\
& 3.6 & 7.46 & 5637.89 & $15,532.79$ & 0.37 \\
$\mathrm{FW}_{75} \mathrm{WS}_{25}$ & 2.0 & 8.20 & 4382.00 & $23,419.00$ & 0.19 \\
& 2.4 & 7.81 & 5182.00 & $18,138.00$ & 0.29 \\
& 2.8 & 7.21 & 3758.00 & $13,431.00$ & 0.28 \\
& 3.2 & 6.80 & 4265.00 & $13,084.00$ & 0.33 \\
& 3.6 & 7.04 & 5705.00 & 9353.00 & 0.61 \\
$\mathrm{FW}_{60} \mathrm{CM}_{20} \mathrm{WS}_{20}$ & 2.0 & 8.16 & 4564.00 & $22,615.00$ & 0.20 \\
& 2.4 & 7.40 & 4823.00 & $17,925.00$ & 0.27 \\
& 2.8 & 8.10 & 4202.00 & $16,467.00$ & 0.26 \\
& 3.2 & 8.30 & 4702.88 & $12,376.00$ & 0.38 \\
& 3.6 & 7.62 & 5488.49 & $11,201.00$ & 0.49 \\
\hline
\end{tabular}


mixtures. Once the OLR rose from 2 to $2.4 \mathrm{~kg} \mathrm{VS} / \mathrm{m}^{3}$.d, VFA:TAC ratios fluctuated between 0.19 and 0.29 which was within the acceptable range, allowing the increase of the loading rate for all the operated digesters [64]. Table 4 illustrated that, at an OLR of $2.4 \mathrm{~kg} \mathrm{VS} / \mathrm{m}^{3}$.d, VFA concentrations varied slightly from 4913 to $3533 \mathrm{mg} / \mathrm{L}$ for $\mathrm{FW}_{75} \mathrm{CM}_{25}$ and 4823 to $4564 \mathrm{mg} / \mathrm{L}$ for $\mathrm{FW}_{60} \mathrm{CM}_{20} \mathrm{WS}_{20}$. While under the same operational conditions, a considerable increase to $5182 \mathrm{mg} / \mathrm{L}$ was identified for $\mathrm{FW}_{75} \mathrm{WS}_{25}$, followed by a significant drop to $3758 \mathrm{mg} / \mathrm{L}$ and, thereafter, by a quick VFA accumulation that persisted until the end of the process. Hence, the identified VFA tendencies indicated that, during the overload period, $\mathrm{FW}_{75} \mathrm{WS}_{25}$ was characterized by an imbalance between the acid-forming phase and methaneforming phase to digest the accumulated fatty acids which was in line with the changes seen in $\mathrm{CH}_{4}$ yield [69]. Meanwhile, a continuous decrease of TAC was examined for both $\mathrm{FW}_{100}$ and $\mathrm{FW}_{75} \mathrm{WS}_{25}$ which was explained by the nature of the feedstock mixtures characterized by a low rate of nitrogen source. For instance, John Wiley (2003) reported that the alkalinity is the effect of the proteinaceous substance's degradation affirming the high alkalinity recorded for the digesters comprising CM [70]. In fact, feedstocks' mixtures including CM and WS separately, added as co-substrates to $\mathrm{FW}$ anaerobic reactors, depicted a significant divergence in terms of alkalinity tendencies ranging from 21,470 to $15,532 \mathrm{mg} \mathrm{CaCO} / / \mathrm{L}_{\text {for }} \mathrm{FW}_{75} \mathrm{CM}_{25}$ and 23,419 to $9353 \mathrm{mg}$ $\mathrm{CaCO}_{3} / \mathrm{L}$ for $\mathrm{FW}_{75} \mathrm{WS}_{25}$, which further ascertained the potential buffering capacity of CM, under variable OLRs. Despite the divergence in terms of VFA and alkalinity fluctuations, the VFA:TAC ratio seemed to be stable only during the start-up phase, affirming the steadiness of the process for OLR of $2 \mathrm{~kg} \mathrm{VS} / \mathrm{m}^{3}$.d and $2.4 \mathrm{~kg} \mathrm{VS} / \mathrm{m}^{3}$.d. However, once the OLR exceeded $2.8 \mathrm{~kg} \mathrm{VS} / \mathrm{m}^{3}$.d, a rise of VFA:TAC above 0.3 was identified for all the digesters indicating that an overloading of the digesters occurred, especially from $3.2 \mathrm{~kg} \mathrm{VS} / \mathrm{m}^{3} . \mathrm{d}$ [71]. Moreover, attaining an OLR of $3.6 \mathrm{VS} /$ $\mathrm{m}^{3}$.d, a significant increase of VFA:TAC ratio was identified for almost all the reactors to peak at 0.61 , entailing the inhibition of the process and the decline in terms of biogas and methane yields. While VFA:TAC ratio remained lower for digesters containing $\mathrm{CM}$, it reached 0.37 at the end of the process, which was not considered as a limiting value of inhibition. Same results were shown by Brambilla et al. (2012) demonstrating that with well-balanced combinations of biowastes, $\mathrm{AD}$ process is sustained in terms of biogas production and methane content, even for VFA:TAC ratios up to 0.5 [67]. On one hand, it was explained by the considerable buffering capacity of $\mathrm{CM}$, which also contributed, to a certain extent, to the maintenance of $\mathrm{FW}_{60} \mathrm{CM}_{20} \mathrm{WS}_{20}$ progress compared to $\mathrm{FW}_{75} \mathrm{WS}_{25}$. On the other hand, it might be due to the potential of CM to supply some TEs required to strengthen the development of methanogens and boost consequently the methane generation [64]. In this context, Yazdanpanah et al. (2018) revealed that an enhanced FW anaerobic treatment was noted owing to the influence of iron $(\mathrm{Fe})$, cobalt $(\mathrm{Co})$, nickel $(\mathrm{Ni})$, selenium (Se), and molybdenum (Mo) to intensify the activity of enzymes in methanogens [72]. Furthermore, working under the same operational conditions, Karlsson et al. (2012) showed the positive impact of TE addition on the degradation efficiencies of VFAs as well as on microbial populations using lab-scale reactors treating FW and fed semi-continuously at a hydraulic retention time (HRT) of 30 days which might explain the stability of digesters including relatively high concentrations of TEs. Hence, the productivity of methanogens was straightly related to both substrates' mixtures, from a qualitative angle, and the organic loading of the reactors from a quantitative angle (Figs. 3 and 4). However, it should be mentioned that it is still a challenge to develop an appropriate TE supplementation strategy. Evidently, either a direct approach which consisted of TE additions or indirect one via co-digestion, the divergence of the feedstock characteristics caused considerable discrepancies in the literature with respect to the levels of optimum TEs needed.

As methanogens are significantly sensitive to $\mathrm{pH}$ fluctuations, a continuous $\mathrm{pH}$ monitoring was carried out. In fact, this latter was definitely influenced by the behaviors of both VFAs and TAC, as alkalinity is considerably required to sustain the $\mathrm{pH}$ within the desired range $(6.8-7.8)$ for microbial growth and alleviate VFA accumulation simultaneously. Therefore, during the start-up period, $\mathrm{pH}$ was 7.20, 8.12, 8.20, and 8.16 for $\mathrm{FW}_{100}, \mathrm{FW}_{75} \mathrm{CM}_{25}, \mathrm{FW}_{75} \mathrm{WS}_{25}$, and $\mathrm{FW}_{60} \mathrm{CM}_{20} \mathrm{WS}_{20}$, respectively. While for OLRs ranging from 2 to $2.8 \mathrm{~kg} \mathrm{VS} / \mathrm{m}^{3}$.d, $\mathrm{pH}$ tended toward neutral values for $\mathrm{FW}_{100}$ and $\mathrm{FW}_{75} \mathrm{WS}_{25}$ (Table 4). Indeed, the identified $\mathrm{pH}$ values were suitable to promote the microbial growth for efficient activity at low OLRs for co-digested FW and WS. However, from an OLR of $3.2 \mathrm{~kg} \mathrm{VS} / \mathrm{m}^{3} . \mathrm{d}$, an acidification of the reactors occurred causing a drop of $\mathrm{pH}$ to around 6. For instance, the maintenance of optimized hydrolytic enzymes' activities at an acidic $\mathrm{pH}$ of around 6 might cause VFA accumulation entailing a reduction of methanogens' activity and, in turn, a drop of SMY [55]. Focusing on reactors comprising manure, higher $\mathrm{pH}$ ranges were obtained to fluctuate around the neutral range during the whole anaerobic process for both $\mathrm{FW}_{75} \mathrm{CM}_{25}$ and $\mathrm{FW}_{60} \mathrm{CM}_{20} \mathrm{WS}_{20}$, which was due to the highly buffering capacity of the added manure providing the microbial communities with an ideal atmosphere for development [73]. However, it should be mentioned that $\mathrm{pH}$ variations did not give any useful index with reference to $\mathrm{ACoD}$ performance, as the measured values varied around neutral ranges for all the co-digested materials under different OLRs and did not change significantly, even when the process was stressed. To this end, $\mathrm{pH}$ adjustment was not always the most appropriate solution to guarantee a 
performant process, which validated the selected option (no $\mathrm{pH}$ regulation during the process). Hence, the combination of different inhibition indicators was crucial for reliable process monitoring. Several researchers have revealed that the follow-up of different factors was more suitable for applications as early warning indicators, particularly for $\mathrm{AD}$ of $\mathrm{FW}$ [64][64][64]. As the ideal indicators were universally unpredictable, it is essential to supply the necessary information with regard to the initial feedstock mixtures and operational conditions, as well as the concerned study area, in order to guarantee a high-performing and sustainable process.

\subsection{Process performance vs digestate quality}

Apart from effective decomposition of the biowaste, it is also crucial to pay attention to AD effluents: biogas and digestate. So, to unlock the full sustainability potential of the process, the by-products need to be efficiently exploited [35]. With regard to the digestate use, certain criteria are required to decide whether digestates can be spread out directly on soil after digestion or if further upcycling processes are needed before utilization [76]. Therefore, full analysis of each digestate collected from different digesters was achieved. Table 4 summarized the physiochemical characteristics of $\mathrm{D} 1, \mathrm{D} 2, \mathrm{D} 3$, and D4, which were gathered from $\mathrm{FW}_{75} \mathrm{WS}_{25}$, $\mathrm{FW}_{60} \mathrm{WS}_{20} \mathrm{CM}_{20}, \mathrm{FW}_{100}$, and $\mathrm{FW}_{75} \mathrm{CM}_{25}$, respectively. The definition of agronomic value is very challenging; there is not a specific quality indicator of each digestate produced from different feedstock mixtures. Therefore, the evaluation of several parameters was needed. Initially, $\mathrm{pH}$ was identified for all the $\mathrm{AD}$ residues, and it was clear that $\mathrm{pH}$ ranged around the neutral value, which was beneficial for digestate exploitation [37]. Indeed, low $\mathrm{pH}$ values boost the heavy metal (HMs) solubility and then cause phytotoxicity issues, thus preventing a direct land application [76]. As one of the steering factors, $\mathrm{MC}$ was first identified where a high water content of around $97 \%$ marked all the digesters. In practice, important moisture can cause certain concerns such as odors, cost-intensive transport, and hard storage facilities [77]. Therefore, a pertinent selection of further criteria was selected as a guide to better understand how to deal with that liquid $\mathrm{AD}$ effluent. Accordingly, $\mathrm{pH}, \mathrm{C}: \mathrm{N}$ ratio, and macro- and micronutrients were additionally measured. As carbon and nitrogen are the most important constituents of organic matter, the carbon to nitrogen rate was evaluated [36]. Indeed, $\mathrm{FW}_{100}$ and $\mathrm{FW}_{75} \mathrm{CM}_{25}$ were characterized by lower $\mathrm{C}: \mathrm{N}$ ratios at around 8.53 and 8.45 , respectively, which was related to the effect of the initial feedstock's characteristics. Both FW and CM were initially relatively rich in nitrogen; then, the total nitrogen was converted by the microbial community into soluble forms and conserved in the digestates D3 and D4. Nevertheless, higher values were considerable for reactors included WS to be about 9.51 for $\mathrm{FW}_{60} \mathrm{WS}_{20} \mathrm{CM}_{20}$ and 12.97 for $\mathrm{FW}_{75} \mathrm{WS}_{25}$. As the latter resulted from a biological treatment of hardly degradable biomass, it featured a residual organic element such as lignocellulosic compounds, which enhanced the tenor of carbon in both of D1 and D2. Even though $\mathrm{FW}_{60} \mathrm{WS}_{20} \mathrm{CM}_{20}$ and $\mathrm{FW}_{75} \mathrm{WS}_{25}$ were characterized by a relatively close initial $\mathrm{C}: \mathrm{N}$ ratio, the generated digestates were qualified by significantly different $\mathrm{C}: \mathrm{N}$ values as a consequence of the different chemical compositions of the mixtures as well as the impact of manure addition in terms of nitrogen conversion during the $\mathrm{AD}$ [76]. However, it should be mentioned that the rate of nitrogen ammonification has to be assessed, as it can lead to potentially phytotoxic digestates preventing a direct land application; then, digestates with higher nitrogen concentration might be phytotoxic and require a post-treatment. Moreover, the nitrogen rate is always associated with potassium $(\mathrm{K})$ and phosphorus $(\mathrm{P})$ concentrations, as the fertilizing effect is mostly influenced by the bioavailability of essential nutrients (N, P, K). Then, the concentrations of $\mathrm{P}$ and $\mathrm{K}$ were checked to be, on average, around 3 and $4 \%$ of TS for all the digestates. The same findings were reported by Beggio et al. (2019) who suggested that for such ranges of $\mathrm{P}$, a digestate post-treatment is needed to increase the phosphorus concentration (Table 5) [78].

Further factors can be harmful to the environment. The $\mathrm{pH}$ level is important to determine innocuousness as it controls the behaviors of metals which are detrimental for soil [17]. Therefore, guidelines are usually established on the total content of heavy metals. Table 6 showed the digestates' characteristics in terms of heavy metal contents as well as some guidelines proposed by the European commission for digestates designed for agricultural use. Indeed, in order to sustain metabolic activity of the cell, some TEs such as Cd, $\mathrm{Cu}, \mathrm{Hg}, \mathrm{Ni}, \mathrm{Pb}, \mathrm{As}$, and $\mathrm{Zn}$ are required.

Table 6 illustrated that zinc ( $\mathrm{Zn})$ was the most abundant trace element, followed by copper $(\mathrm{Cu})$ and nickel $(\mathrm{Ni})$. However, D2 and D4 were characterized by a relatively high rate of TEs, which was due to the initial contribution of $\mathrm{CM}$,

Table 5 Characteristics of the gathered digestates

\begin{tabular}{llrrrr}
\hline Parameters & Units & \multicolumn{1}{c}{ D1 } & \multicolumn{1}{c}{ D2 } & \multicolumn{1}{c}{ D3 } & \multicolumn{1}{c}{ D4 } \\
\hline $\mathrm{pH}$ & - & 7.49 & 7.51 & 7.02 & 8.13 \\
Moisture content (MC) & \% of FM & 96.70 & 95.90 & 97.50 & 97.30 \\
Carbon (C) & \% of FM & 37.60 & 35.20 & 40.10 & 37.20 \\
Nitrogen (N) & \% of FM & 2.90 & 3.70 & 4.70 & 4.40 \\
C:N ratio & - & 12.97 & 9.51 & 8.53 & 8.45 \\
Phosphorus (P) & \% of TS & 3.02 & 3.17 & 2.87 & 2.91 \\
Potassium (K) & \% of TS & 4.16 & 4.04 & 4.21 & 4.86 \\
Magnesium (Mg) & \% of TS & 0.4 & 0.65 & 0.38 & 0.81 \\
Calcium carbonate & \% of TS & 5.68 & 8.31 & 5.35 & 11.10 \\
$\quad$ CaCO3) & & & & & \\
\hline
\end{tabular}


Table 6 The limits of total metal contents with reference to the European commission [17] [79]

\begin{tabular}{|c|c|c|c|c|c|c|}
\hline \multirow[t]{2}{*}{ HMs (mg/ kg TS) } & \multicolumn{4}{|c|}{ Digestate } & \multicolumn{2}{|c|}{$\begin{array}{l}\text { Standards of } \\
\text { digestate (EU rec- } \\
\text { ommendations) }\end{array}$} \\
\hline & D1 & D2 & D3 & D4 & 2015 & 2025 \\
\hline Lead $(\mathrm{Pb})$ & 2.33 & 2.46 & 2.29 & 2.54 & 500 & 300 \\
\hline Copper $(\mathrm{Cu})$ & 38.86 & 46.02 & 44.07 & 60.02 & 800 & 600 \\
\hline Zinc (Zn) & 165.64 & 185.07 & 167.65 & 223.41 & 2000 & 1500 \\
\hline Nickel (Ni) & 8.08 & 7.24 & 6.48 & 9.00 & 200 & 100 \\
\hline Cadmium (Cd) & 0.32 & 0.40 & 0.35 & 0.38 & 5 & 2 \\
\hline Arsenic (As) & 1.40 & 1.95 & 1.70 & 1.76 & - & - \\
\hline Mercury $(\mathrm{Hg})$ & 0.02 & 0.05 & 0.07 & 0.09 & 5 & 2 \\
\hline
\end{tabular}

particularly in terms of $\mathrm{Zn}, \mathrm{Cu}$, and Ni. As methanogenesis is one of the most trace element-enriched enzymatic pathways in biology, the intensive concentrations of certain TEs in digesters, including manure such as $\mathrm{FW}_{75} \mathrm{CM}_{25}$ and $\mathrm{FW}_{60} \mathrm{CM}_{20} \mathrm{WS}_{20}$, were predictable from the SMY recorded (Fig. 5). Some researchers have reported that the trace element requirements depend on the used substrates as well as the methanogenesis demands [45][45]. Moreover, special attention was paid to cadmium (Cd), as it is relatively soluble on soils, readily consumed by crops, and then is toxic to humans [80]. However, the collected digestates were characterized by acceptable $\mathrm{Cd}$ concentrations, which were below the requested ranges. As the treated biomasses were initially characterized by low contents in terms of heavy metals, the examined digestates were also outlined by heavy metal concentrations below the limits imposed by the European Standards.

\section{Perspective}

This research work aimed, essentially, to handle various types of biowastes abundantly generated in Tunisia using biological treatments. Therefore, aerobic and anaerobic processes were carried out simultaneously (Fig. 1) to take advantage as much as possible of the selected organic wastes and upcycle efficiently the obtained AD slurry. In fact, starting with anaerobic process, the mono-digestion of FW implied as a first step an alarming concern in terms of process performance as well as AD effluent quality. To this end, overcoming FW-AD failure was ensured by agricultural residue addition, enhancing SBY, SMY, as well as digestate quality. However, this latter created the second AD issue which consisted of the generation of a huge volume of the AD slurry which required a huge consumption of energy to achieve an efficient post-treatment such as sanitization or nutrient recovery restricting the effectiveness of the anaerobic treatment. Hence, digestate upcycling became a priority to unlock AD sustainability. When it comes to aerobic digestion, a significant quantity of fresh water was required to supply the composters treating FW and WS, which might cause a further issue for a semi-arid area such as Tunisia, suffering from water shortage. Thus, to meet simultaneously the concerns occurring during aerobic and anaerobic processes, digestate was opted to be upcycled in a cost-effective way and exploited as an unconventional moisturizing agent in one hand and as a composting process booster in the other hand.

\section{Conclusion}

To efficiently manage organic residues and unlock the full sustainability of AD potential, this research work aimed to develop quantitative relationships between the physical properties of the different types of organic residues abundantly generated in Tunisia. Therefore, a closed cycle "biowaste to bioenergy" treatment, mainly of food waste, was examined. To this end, ACoD of food and agricultural residues was examined. To this end, $\mathrm{ACoD}$ of $\mathrm{FW}, \mathrm{CM}$, and WS were examined under semi-continuous conditions. Steering parameters were monitored such as variable substrates' mixture ratios, adjusted C:N, and increased OLRs. Results showed that the most appropriate operational scenario was a feedstock ratio of $\mathrm{FW}: \mathrm{CM}=75: 25$ and operating at an OLR of $3.4 \mathrm{~kg} \mathrm{VS} / \mathrm{m}^{3}$.d. However, with regard to $\mathrm{FW}_{100}$, $\mathrm{FW}_{60} \mathrm{CM}_{20} \mathrm{WS}_{20}$, and $\mathrm{FW}_{75} \mathrm{WS}_{25}$, lower biogas and methane yields were recorded. This might be due to the relatively high initial C:N ratio for digesters comprising WS and the use of untreated raw materials. However, the latter suited the operational conditions required by the project. For sustainable biological treatments, special attention had to be paid to the efficient recovery of both $\mathrm{AD}$ effluents: biogas and digestate. Therefore, digestates were collected from different anaerobic reactors to be characterized in order to determine how $\mathrm{AD}$ residues might be effectively upcycled. 
Therefore, additional works were achieved to evaluate the post-treatment of the generated effluents.

Abbreviations $F W$ : Food waste; $A D$ : Anaerobic digestion; $A C o D$ : Anaerobic co-digestion; WS: Wheat straw; $C M$ : cattle manure; $C N$ : Carbon to nitrogen; OLRs: organic loading rates; $M C$ : Moisture content; VS: Volatile solids; EC: Salinity; $G H G$ : Greenhouse gases; D: Digestate; TEs: Trace elements; HRT: Hydraulic retention time; TS: Total solids; VS: Volatile solids; VFAs: Volatile fatty acids; TAC: Alkaline buffer capacity; $(100 \% F W): \mathrm{FW}_{100} ;(F W W S=75: 25): \mathrm{FW}_{75} \mathrm{WS}_{25}$; $(F W C M=75: 25): \mathrm{FW}_{75} \mathrm{CM}_{25} ;(F W W S C M=60: 20: 20): \mathrm{FW}_{60} \mathrm{WS}_{20}$ $\mathrm{CM}_{20}$; $S B Y$ : Specific biogas yield; $S M Y$ : Specific methane yield

Acknowledgements The authors express their sincere appreciation to Technical Lab for Waste Management and Bioenergy, University of Rostock, Germany, for co-funding this study.

Author contribution Conceptualization, N.E.H.C.; methodology, N.E.H.C.; formal analysis, N.E.H.C. and N.E.; investigation, N.E.H.C.; data curation, N.E.H.C. and N.E.; writing-original draft preparation, N.E.H.C.; writing-review and editing, N.E.H.C.; supervision, A.N. and M.N.

Funding Open Access funding enabled and organized by Projekt DEAL.

Data availability All data generated or analyzed during this study are included in this published article.

\section{Declarations}

Ethics approval and consent to participate Not applicable.

Consent for publication Not applicable.

Conflict of interest The authors declare no competing interests.

Open Access This article is licensed under a Creative Commons Attribution 4.0 International License, which permits use, sharing, adaptation, distribution and reproduction in any medium or format, as long as you give appropriate credit to the original author(s) and the source, provide a link to the Creative Commons licence, and indicate if changes were made. The images or other third party material in this article are included in the article's Creative Commons licence, unless indicated otherwise in a credit line to the material. If material is not included in the article's Creative Commons licence and your intended use is not permitted by statutory regulation or exceeds the permitted use, you will need to obtain permission directly from the copyright holder. To view a copy of this licence, visit http://creativecommons.org/licenses/by/4.0/.

\section{References}

1. Slorach PC, Jeswani HK, Cuéllar-Franca R, Azapagic A (2019) Environmental sustainability of anaerobic digestion of household food waste. J Environ Manage 236:798-814. https://doi.org/10. 1016/j.jenvman.2019.02.001

2. Mahjoub O, Jemai A, Haddaoui I (2020) Waste management in Tunisia - what could the past bring to the future? In: Negm AM, Shareef N (eds) Waste Management in MENA Regions. Springer International Publishing, Cham, pp 35-69
3. Vaverková MD (2019) Landfill impacts on the environmentreview. Geosciences 9:431. https://doi.org/10.3390/geoscience s9100431

4. European Parliament. Directorate General for Parliamentary Research Services., Oakdene Hollins., Wuppertal Institute (2017) Towards a circular economy: waste management in the EU. Publications Office, LU

5. Fava F, Totaro G, Diels L et al (2015) Biowaste biorefinery in Europe: opportunities and research \& development needs. New Biotechnol 32:100-108. https://doi.org/10.1016/j.nbt.2013.11.003

6. He P, Chen L, Shao L et al (2019) Municipal solid waste (MSW) landfill: a source of microplastics? -Evidence of microplastics in landfill leachate. Water Res 159:38-45. https://doi.org/10.1016/j. watres.2019.04.060

7. Chaabane W (2019) Solid waste management in tourism destinations in Tunisia. https://doi.org/10.18453/ROSDOK_ID00002705

8. Lin L, Xu F, Ge X, Li Y (2018) Improving the sustainability of organic waste management practices in the food-energy-water nexus: a comparative review of anaerobic digestion and composting. Renew Sustain Energy Rev 89:151-167. https://doi.org/10. 1016/j.rser.2018.03.025

9. Lin L, Xu F, Ge X, Li Y (2019) Chapter Four - Biological treatment of organic materials for energy and nutrients production-anaerobic digestion and composting. In: Li Y, Ge X (eds) Advances in Bioenergy. Elsevier, pp 121-181

10. Bolzonella D, Fatone F, Gottardo M, Frison N (2018) Nutrients recovery from anaerobic digestate of agro-waste: techno-economic assessment of full scale applications. J Environ Manage 216:111-119. https://doi.org/10.1016/j.jenvman.2017.08.026

11. Chaher NEH, Chakchouk M, Nassour A et al (2020) Potential of windrow food and green waste composting in Tunisia. Environ Sci Pollut Res. https://doi.org/10.1007/s11356-020-10264-7

12. Bhatia SK, Joo H-S, Yang Y-H (2018) Biowaste-to-bioenergy using biological methods - a mini-review. Energy Convers Manage 177:640-660. https://doi.org/10.1016/j.enconman.2018.09. 090

13. Pardo G, Moral R, del Prado A (2017) SIMSWASTE-AD - a modelling framework for the environmental assessment of agricultural waste management strategies: anaerobic digestion. Sci Total Environ 574:806-817. https://doi.org/10.1016/j.scitotenv.2016.09.096

14. Wang H, Wang D, Zhou X (2018) Analysis on the trend of water quality in Haihe River Basin from 2005 to 2017. J Geosci Environ Protect 06:1-7. https://doi.org/10.4236/gep.2018.611001

15. Koszel M, Lorencowicz E (2015) Agricultural use of biogas digestate as a replacement fertilizers. Agric Agric Sci Procedia 7:119-124. https://doi.org/10.1016/j.aaspro.2015.12.004

16. Martens W, Böhm R (2009) Overview of the ability of different treatment methods for liquid and solid manure to inactivate pathogens. Biores Technol 100:5374-5378. https://doi.org/10.1016/j. biortech.2009.01.014

17. Al Seadi T, Drosg B, Fuchs W, et al (2013) 12 - Biogas digestate quality and utilization. In: Wellinger A, Murphy J, Baxter D (eds) The Biogas Handbook. Woodhead Publishing, pp 267-301

18. Shrestha B, Hernandez R, Fortela DLB et al (2020) A review of pretreatment methods to enhance solids reduction during anaerobic digestion of municipal wastewater sludges and the resulting digester performance: implications to future urban biorefineries. Appl Sci 10:9141. https://doi.org/10.3390/app10249141

19. Seruga P, Krzywonos M, Paluszak Z et al (2020) Pathogen reduction potential in anaerobic digestion of organic fraction of municipal solid waste and food waste. Molecules 25:275. https://doi.org/ 10.3390/molecules25020275

20. Arelli V, Juntupally S, Begum S, Anupoju GR (2020) Significance of pretreatment in enhancing the performance of dry anaerobic digestion of food waste: an insight on full-scale implementation 
strategy with theoretical analogy. Processes 8:1018. https://doi. org/10.3390/pr8091018

21. Zhang Y, Kusch-Brandt S, Heaven S, Banks CJ (2020) Effect of pasteurisation on methane yield from food waste and other substrates in anaerobic digestion. Processes 8:1351. https://doi.org/ 10.3390/pr8111351

22. Barco H, Oribe-Garcia I, Vargas-Viedma MV et al (2019) New methodology for facilitating food wastage quantification. Identifying gaps and data inconsistencies. J Environ Manage 234:512524. https://doi.org/10.1016/j.jenvman.2018.11.037

23. Awasthi SK, Sarsaiya S, Awasthi MK et al (2020) Changes in global trends in food waste composting: research challenges and opportunities. Biores Technol 299:122555. https://doi.org/10. 1016/j.biortech.2019.122555

24. Arelli V, Begum S, Anupoju GR et al (2018) Dry anaerobic codigestion of food waste and cattle manure: impact of total solids, substrate ratio and thermal pretreatment on methane yield and quality of biomanure. Biores Technol 253:273-280. https://doi. org/10.1016/j.biortech.2018.01.050

25. Sindhu R, Gnansounou E, Rebello S et al (2019) Conversion of food and kitchen waste to value-added products. J Environ Manage. https://doi.org/10.1016/j.jenvman.2019.02.053

26. Zhao Y, Sun F, Yu J et al (2018) Co-digestion of oat straw and cow manure during anaerobic digestion: stimulative and inhibitory effects on fermentation. Biores Technol 269:143-152. https://doi. org/10.1016/j.biortech.2018.08.040

27. Zhang J, Mao L, Nithya $K$ et al (2019) Optimizing mixing strategy to improve the performance of an anaerobic digestion waste-toenergy system for energy recovery from food waste. Appl Energy 249:28-36. https://doi.org/10.1016/j.apenergy.2019.04.142

28. Chaher NEH, Hemidat S, Thabit Q et al (2020) Potential of sustainable concept for handling organic waste in Tunisia. Sustainability 12:8167. https://doi.org/10.3390/su12198167

29. Zahan Z, Georgiou S, Muster TH, Othman MZ (2018) Semi-continuous anaerobic co-digestion of chicken litter with agricultural and food wastes: a case study on the effect of carbon/nitrogen ratio, substrates mixing ratio and organic loading. Biores Technol 270:245-254. https://doi.org/10.1016/j.biortech.2018.09.010

30. Kainthola J, Kalamdhad AS, Goud VV (2019) A review on enhanced biogas production from anaerobic digestion of lignocellulosic biomass by different enhancement techniques. Process Biochem. https://doi.org/10.1016/j.procbio.2019.05.023

31. Hassan M, Ding W, Umar M, Rasool G (2017) Batch and semicontinuous anaerobic co-digestion of goose manure with alkali solubilized wheat straw: a case of carbon to nitrogen ratio and organic loading rate regression optimization. Biores Technol 230:24-32. https://doi.org/10.1016/j.biortech.2017.01.025

32. Menon A, Ren F, Wang J-Y, Giannis A (2016) Effect of pretreatment techniques on food waste solubilization and biogas production during thermophilic batch anaerobic digestion. J Mater Cycles Waste Manag 18:222-230. https://doi.org/10.1007/ s10163-015-0395-6

33. Di Maria F, Sordi A, Micale C (2012) Energy production from mechanical biological treatment and composting plants exploiting solid anaerobic digestion batch: an Italian case study. Energy Convers Manage 56:112-120. https://doi.org/10.1016/j.encon man.2011.11.023

34. Zahan Z, Maazuza O, Muster T (2017) Bioreactor performances in continuous anaerobic co-digestion of chicken litter with agroindustrial wastes: effect of $\mathrm{C} / \mathrm{N}$ ratio, organic loading and lignocellulose fractionation

35. Corrado S, Caldeira C, Eriksson M et al (2019) Food waste accounting methodologies: challenges, opportunities, and further advancements. Glob Food Sec 20:93-100. https://doi.org/ 10.1016/j.gfs.2019.01.002
36. Guarino G, Carotenuto C, Di Cristofaro F et al (2016) Does the c/n ration really affect the biomethane yield? a three years investigation of buffalo manure digestion. Chem Eng Trans 49:463-468. https://doi.org/10.3303/CET1649078

37. Saveyn H, Eder P, Institute for Prospective Technological Studies, (2014) End-of-waste criteria for biodegradable waste subjected to biological treatment (compost \& digestate): technical proposals. Publications Office, Luxembourg

38. Ngan NVC, Chan FMS, Nam TS et al (2020) Anaerobic digestion of rice straw for biogas production. In: Gummert M, Hung NV, Chivenge P, Douthwaite B (eds) Sustainable Rice Straw Management. Springer International Publishing, Cham, pp 65-92

39. Jin Y, Li Y, Li J (2016) Influence of thermal pretreatment on physical and chemical properties of kitchen waste and the efficiency of anaerobic digestion. J Environ Manage 180:291-300. https://doi.org/10.1016/j.jenvman.2016.05.047

40. Parra-Orobio BA, Donoso-Bravo A, Ruiz-Sánchez JC et al (2018) Effect of inoculum on the anaerobic digestion of food waste accounting for the concentration of trace elements. Waste Manage 71:342-349. https://doi.org/10.1016/j.wasman.2017.09.040

41. Kuruti K, Begum S, Ahuja S et al (2017) Exploitation of rapid acidification phenomena of food waste in reducing the hydraulic retention time (HRT) of high rate anaerobic digester without conceding on biogas yield. Biores Technol 226:65-72. https://doi.org/ 10.1016/j.biortech.2016.12.005

42. VDI 4630 - Fermentation of organic materials - characterization of the substrate, sampling, collection of material data, fermentation tests

43. Amri F (2018) Carbon dioxide emissions, total factor productivity, ICT, trade, financial development, and energy consumption: testing environmental Kuznets curve hypothesis for Tunisia. Environ Sci Pollut Res 25:33691-33701. https://doi.org/10.1007/ s11356-018-3331-1

44. Zheng Z, Liu J, Yuan X et al (2015) Effect of dairy manure to switchgrass co-digestion ratio on methane production and the bacterial community in batch anaerobic digestion. Appl Energy 151:249-257. https://doi.org/10.1016/j.apenergy.2015.04.078

45. Akturk AS, Demirer GN (2020) Improved food waste stabilization and valorization by anaerobic digestion through supplementation of conductive materials and trace elements. Sustainability 12:5222. https://doi.org/10.3390/su12125222

46. Choong YY, Norli I, Abdullah AZ, Yhaya MF (2016) Impacts of trace element supplementation on the performance of anaerobic digestion process: a critical review. Biores Technol 209:369-379. https://doi.org/10.1016/j.biortech.2016.03.028

47. Fermoso FG, van Hullebusch E, Collins G, et al (2019) Biogeochemistry of major elements in anaerobic digesters: carbon, nitrogen, phosphorus, sulfur and iron. In: Trace Elements in Anaerobic Biotechnologies. IWA Publishing, pp 1-22

48. Fermoso FG, van Hullebusch E, Collins G, et al (2019) Trace elements in anaerobic biotechnologies. IWA Publishing

49. Vintiloiu A, Lemmer A, Oechsner H, Jungbluth T (2012) Mineral substances and macronutrients in the anaerobic conversion of biomass: an impact evaluation. Eng Life Sci 12:287-294. https://doi. org/10.1002/elsc.201100159

50. Zahan Z, Othman MZ (2019) Effect of pre-treatment on sequential anaerobic co-digestion of chicken litter with agricultural and food wastes under semi-solid conditions and comparison with wet anaerobic digestion. Biores Technol 281:286-295. https://doi.org/ 10.1016/j.biortech.2019.01.129

51. Dioha IJ, Ikeme CH, Nafi'u T, Soba NI (2013) Effect of carbon to nitrogen ratio on biogas production. 1:10

52. Chatterjee B, Mazumder D (2019) Role of stage-separation in the ubiquitous development of anaerobic digestion of organic fraction of municipal solid waste: a critical review. Renew Sustain Energy Rev 104:439-469. https://doi.org/10.1016/j.rser.2019.01.026 
53. Bi S, Hong X, Yang H et al (2020) Effect of hydraulic retention time on anaerobic co-digestion of cattle manure and food waste. Renew Energy 150:213-220. https://doi.org/10.1016/j.renene. 2019.12.091

54. Kainthola J, Kalamdhad AS, Goud VV (2020) Optimization of process parameters for accelerated methane yield from anaerobic co-digestion of rice straw and food waste. Renew Energy 149:1352-1359. https://doi.org/10.1016/j.renene.2019.10.124

55. Rabii A, Aldin S, Dahman Y, Elbeshbishy E (2019) A review on anaerobic co-digestion with a focus on the microbial populations and the effect of multi-stage digester configuration. Energies 12:1106. https://doi.org/10.3390/en12061106

56. Nordell E, Nilsson B, Nilsson Påledal S et al (2016) Co-digestion of manure and industrial waste - the effects of trace element addition. Waste Manage 47:21-27. https://doi.org/10.1016/j.wasman. 2015.02.032

57. Owamah HI, Izinyon OC (2015) The effect of organic loading rates (OLRs) on the performances of food wastes and maize husks anaerobic co-digestion in continuous mode. Sustain Energy Technol Assess 11:71-76. https://doi.org/10.1016/j.seta.2015.06.002

58. Song H, Zhang Y, Kusch-Brandt S, Banks CJ (2020) Comparison of variable and constant loading for mesophilic food waste digestion in a long-term experiment. Energies 13:1279. https://doi.org/ 10.3390/en 13051279

59. Rajput AA, Sheikh Z (2019) Effect of inoculum type and organic loading on biogas production of sunflower meal and wheat straw. Sustain Environ Res 29:4. https://doi.org/10.1186/ s42834-019-0003-x

60. Sembera C, Macintosh C, Astals S, Koch K (2019) Benefits and drawbacks of food and dairy waste co-digestion at a high organic loading rate: a Moosburg WWTP case study. Waste Manage 95:217-226. https://doi.org/10.1016/j.wasman.2019.06.008

61. Achinas S, Achinas V, Euverink GJW (2020) Chapter 2 - Microbiology and biochemistry of anaerobic digesters: an overview. In: Singh L, Yousuf A, Mahapatra DM (eds) Bioreactors. Elsevier, pp $17-26$

62. Pohl M, Heeg K, Mumme J (2013) Anaerobic digestion of wheat straw - performance of continuous solid-state digestion. Biores Technol 146:408-415. https://doi.org/10.1016/j.biortech.2013.07. 101

63. Bong CPC, Lim LY, Lee CT et al (2018) The characterisation and treatment of food waste for improvement of biogas production during anaerobic digestion - a review. J Clean Prod 172:15451558. https://doi.org/10.1016/j.jclepro.2017.10.199

64. Li L, He Q, Wei Y et al (2014) Early warning indicators for monitoring the process failure of anaerobic digestion system of food waste. Biores Technol 171:491-494. https://doi.org/10.1016/j. biortech.2014.08.089

65. Martín-González L, Font X, Vicent T (2013) Alkalinity ratios to identify process imbalances in anaerobic digesters treating source-sorted organic fraction of municipal wastes. Biochem Eng J 76:1-5. https://doi.org/10.1016/j.bej.2013.03.016

66. Chen S, Zhang J, Wang X (2015) Effects of alkalinity sources on the stability of anaerobic digestion from food waste. Waste Manag Res 33:1033-1040. https://doi.org/10.1177/0734242X15602965

67. Brambilla M, Araldi F, Marchesi M et al (2012) Monitoring of the startup phase of one continuous anaerobic digester at pilot scale level. Biomass Bioenerg 36:439-446. https://doi.org/10.1016/j. biombioe.2011.11.009

68. Ambrose HW, Philip L, Suraishkumar GK et al (2020) Anaerobic co-digestion of activated sludge and fruit and vegetable waste: evaluation of mixing ratio and impact of hybrid (microwave and hydrogen peroxide) sludge pre-treatment on two-stage digester stability and biogas yield. J Water Process Eng 37:101498. https:// doi.org/10.1016/j.jwpe.2020.101498

69. Wang K, Yin J, Shen D, Li N (2014) Anaerobic digestion of food waste for volatile fatty acids (VFAs) production with different types of inoculum: effect of pH. Biores Technol 161:395-401. https://doi.org/10.1016/j.biortech.2014.03.088

70. (2003) The microbiology of anaerobic digesters, 1st ed. John Wiley \& Sons, Ltd

71. Ghinea C, Leahu A (2020) Monitoring of fruit and vegetable waste composting process: relationship between microorganisms and physico-chemical parameters. Processes 8:302. https://doi. org/10.3390/pr8030302

72. Yazdanpanah A, Ghasimi DSM, Kim MG et al (2018) Impact of trace element supplementation on mesophilic anaerobic digestion of food waste using Fe-rich inoculum. Environ Sci Pollut Res 25:29240-29255. https://doi.org/10.1007/s11356-018-2832-2

73. Anukam A, Mohammadi A, Naqvi M, Granström K (2019) A review of the chemistry of anaerobic digestion: methods of accelerating and optimizing process efficiency. Processes 7:504. https:// doi.org/10.3390/pr7080504

74. Franke-Whittle IH, Walter A, Ebner C, Insam H (2014) Investigation into the effect of high concentrations of volatile fatty acids in anaerobic digestion on methanogenic communities. Waste Manag 34:2080-2089. https://doi.org/10.1016/j.wasman.2014.07.020

75. Jiang J, Zhang Y, Li K et al (2013) Volatile fatty acids production from food waste: effects of $\mathrm{pH}$, temperature, and organic loading rate. Biores Technol 143:525-530. https://doi.org/10.1016/j.biort ech.2013.06.025

76. Teglia C, Tremier A, Martel J-L (2011) Characterization of solid digestates: part 1, review of existing indicators to assess solid digestates agricultural use. Waste Biomass Valor 2:43-58. https:// doi.org/10.1007/s12649-010-9051-5

77. Hosseini Koupaie E, Azizi A, Bazyar Lakeh AA et al (2019) Comparison of liquid and dewatered digestate as inoculum for anaerobic digestion of organic solid wastes. Waste Manage 87:228-236. https://doi.org/10.1016/j.wasman.2019.02.014

78. Beggio G, Schievano A, Bonato T et al (2019) Statistical analysis for the quality assessment of digestates from separately collected organic fraction of municipal solid waste (OFMSW) and agro-industrial feedstock. Should input feedstock to anaerobic digestion determine the legal status of digestate? Waste Manage 87:546-558. https://doi.org/10.1016/j.wasman.2019.02.040

79. Örtl E (2018) Quality assurance of compost and digestate. Umweltbundesamt

80. Aydi A (2015) Assessment of heavy metal contamination risk in soils of landfill of Bizerte (Tunisia) with a focus on application of pollution indicators. Environ Earth Sci 74:3019-3027. https:// doi.org/10.1007/s 12665-015-4332-8

81. Somashekar RK, Verma R, Naik MA Potential of biogas production from food waste in a uniquely designed reactor under lab conditions. 7

Publisher's note Springer Nature remains neutral with regard to jurisdictional claims in published maps and institutional affiliations. 